Review

\title{
Biopolymeric Mucin and Synthetic Polymer Analogs: Their Structure, Function and Role in Biomedical Applications
}

\author{
Sundar P. Authimoolam and Thomas D. Dziubla * \\ Department of Chemical and Materials Engineering, College of Engineering, University of Kentucky, \\ 177. Paul Anderson Tower, Lexington, KY 40506, USA; sundar.prasanth@uky.edu \\ * Correspondence: dziubla@engr.uky.edu; Tel.: +1-859-257-4063; Fax: +1-859-323-1929 \\ Academic Editor: Esmaiel Jabbari \\ Received: 7 December 2015; Accepted: 24 February 2016; Published: 2 March 2016
}

\begin{abstract}
Mucin networks are viscoelastic fibrillar aggregates formed through the complex self-association of biopolymeric glycoprotein chains. The networks form a lubricious, hydrated protective shield along epithelial regions within the human body. The critical role played by mucin networks in impacting the transport properties of biofunctional molecules (e.g., biogenic molecules, probes, nanoparticles), and its effect on bioavailability are well described in the literature. An alternate perspective is provided in this paper, presenting mucin's complex network structure, and its interdependent functional characteristics in human physiology. We highlight the recent advances that were achieved through the use of mucin in diverse areas of bioengineering applications (e.g., drug delivery, biomedical devices and tissue engineering). Mucin network formation is a highly complex process, driven by wide variety of molecular interactions, and the network possess structural and chemical variations, posing a great challenge to understand mucin's bulk behavior. Through this review, the prospective potential of polymer based analogs to serve as mucin mimic is suggested. These analog systems, apart from functioning as an artificial model, reducing the current dependency on animal models, can aid in furthering our fundamental understanding of such complex structures.
\end{abstract}

Keywords: mucin; biomimic; bioapplication; polymer analog; polymer networks; tissue engineering; drug delivery

\section{Introduction}

Mucin networks are viscoelastic lubricious layers, lining the luminal surface of many regions within the human body. The network formation results from a continuous deposition of biopolymeric glycoprotein chains. Through the structural, chemical and barrier properties, these functional coatings serve a critical role in maintaining human health. When these coatings are lost, a perceivable dryness along the cornea (dry eyes), buccal cavity (xerostomia) or upper respiratory tract can occur, rendering the epithelium highly vulnerable to pathogens (e.g., intestinal inflammation from loss of gastrointestinal mucus). Despite mucin's importance, it is often simply considered a barrier to be overcome, for instance, its role in affecting drug permeability and therapeutic bioavailability. Here, we present a detailed review highlighting the unique structure and functional role that mucin plays and also present avenues by which mucin considerations can be built into biomaterial/biomedical designs, including the capability of synthetic polymeric mucin analogs in the potential therapeutic framework. 


\section{Natural Mucin Network Structure, Formation and Molecular Properties}

\subsection{Molecular Properties}

Mucins are glycoproteins secreted by epithelial goblet cells, and mucus cells present in submucosal glands [1]. For instance, in the oral mucosal surface, the acinar epithelial cells, and in gastric region, the foveolar cells are primarily responsible for mucin production. These mucin glycoproteins are key constituents comprising the lubricating layer, and in the oral cavity, they primarily determine the rheological properties of saliva [2-4]. These glycoproteins can be broadly categorized on the basis of their molecular weight $\left(M_{\mathrm{w}}\right)$ and degree of interconnection. In the oral cavity, the low $M_{\mathrm{w}}$ glycoprotein chains of 200-300 kDa, made of a single glycosylated peptide chain, form an important fraction of free flowing saliva and they help regulate bacterial clearance. While, the high $M_{\mathrm{w}}$ glycoproteins of $>1000 \mathrm{kDa}$ constitute a significant part of oral salivary films, or mucin network coats (bound saliva), which helps form a protective epithelial shield [5-7]. In the buccal region, these functional coats are more commonly referred to as oral mucus, mucin coats or the salivary pellicle [2-4].

In general, mucin contains a polypeptide backbone which is predominantly made of serine, alanine, proline, glycine and threonine ( $75 \%$ of total amino acid content) [8-10]. The oligosaccharide side chain decorates the peptide backbone, which are covalently grafted via $O$-glycosidic linkages (Figure 1a). The linkages were formed between hydroxyl groups in peptide backbone (e.g., serine, threonine) to the sialic acid or L-fucose subunits present in oligosaccharide chains [10-12]. The $M_{\mathrm{w}}$ of the hydrophilic oligosaccharide side chains are highly polydisperse, and vary substantially between species and mucosal surfaces, and constitute nearly $50 \%-80 \%$ of mucin's dry weight $[11,13]$. These carbohydrate chains are composed of the monosaccharide subunits, galactose, sialic acid, which renders mucin with hydrophilic properties [11-13]. Mucin chains also contain non-glycosylated regions that are rich in cysteine moieties, enabling interchain disulfide crosslinking. The non-glycosylated regions are vulnerable to proteolytic cleavage due to lack of oligosaccharide chains [12]. Thereby, under proteolytic conditions, the mucin chains can break-down into smaller subunits. In oral environment, such mechanism aid in forming the free-flowing saliva [4,14].

Mucin possesses a bottlebrush-like structure. The high molecular weight glycoproteins are structurally analogous to filaments possessing a high structural aspect ratio (L/D) [15]. These glycoproteins crosslink via disulfide bonds, and forms longer branched structures (mucin multimers). Subsequently, the multimers can randomly undergo higher order associations with glycoprotein chains and with small molecule proteins (Figure $1 \mathrm{~b}$ ). These associations are driven by a wide variety of molecular interactions such as disulfide bridging, hydrophobic interactions, electrostatic forces and hydrogen bonding, forming a more intact, 3 -dimensional viscoelastic biopolymeric network $[8,16]$. For instance, in the oral cavity, the salivary proteins adsorb onto the mucosal epithelial surface. The process is accompanied by continuous deposition of glycoproteins chains (self-association) and complexation with oral proteins [4], forming oral mucus coats.

\subsection{Mucin Network Structural Characteristics}

Morphologically, in the initial formation stage of a developing mucin coat, the glycoprotein creates granular inhomogeneous deposits. However, at greater time scales, due to prolonged fibrillar depositions and a complexation process, those granular structures merge into a continuous interwoven morphology (reticulated structures) [17,18]. For instance, Lie et al., (1976) [18] used hydroxyapatite/epoxy resin splints as a model enamel substrate in studying the mechanism of mucin pellicle formation. In their study, the splints were bound to the buccal surface. At relatively short time scales $(\sim 2 \mathrm{~h})$, the pellicles formed heterogeneous granular structures with a thickness ranging from 25 to $125 \mathrm{~nm}$. While at greater time scales $(\sim 24 \mathrm{~h})$, they formed a continuous thick film of $\sim 550$ to $900 \mathrm{~nm}$ [17-20]. In a more recent study, Baek et al., (2009) used optical approaches to study the time-dependent salivary pellicle formation over teeth, in agreement with the earlier results, this study suggested a similar structural surface growth tendency [21]. Interestingly, such growth can 
also be observed in multilayered particulate based systems. For instance, in our recent work [15], we demonstrated that by utilizing a filamentous micellar structure analogical to mucin glycoproteins, a similar growth tendency can be recreated via affinity driven layer-by-layer deposition approach. The surface growth tendency during micellar deposition follows a lateral-expansion mode, initially forming localized islands. These clusters, due to the high aspect ratio of filomicelle, easily bridged with each other to form reticulated structures similar to mucin. Similarly, Hong et al., (2005) in their study suggested that micellar aggregates possess close semblance with mucin aggregation tendency [20].

(a)

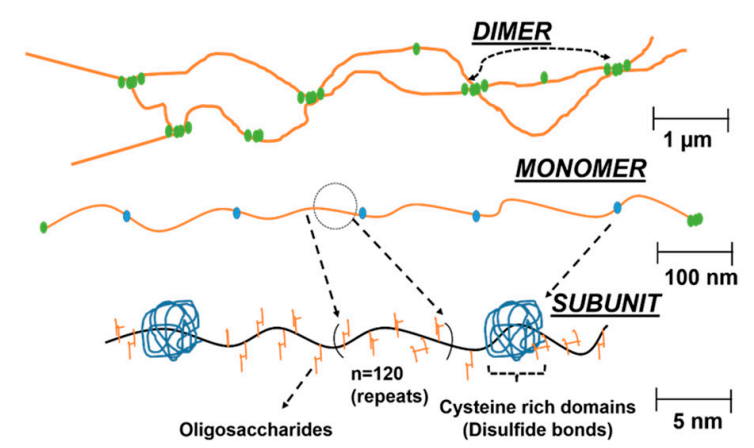

(b)

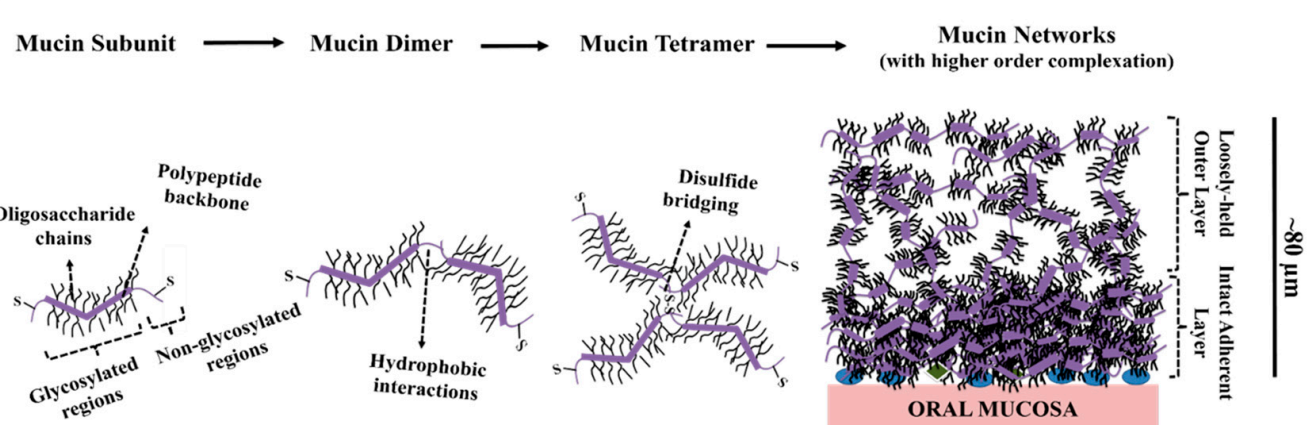

Figure 1. Mucin glycoprotein's molecular properties, and its network formation ability. (a) A simplified scheme shows the composition of mucin glycoproteins, its subunit, monomer, and dimer; (b) Progression of higher order complexation of mucin glycoproteins resulting in the formation of a mucin network over oral mucosal surface. This scheme demonstrates the progression of high-order complexation process, which results in formation of mucin aggregates. Mucin aggregates invariably contain two-distinct zones: the more intact adherent mucin layers, and loosely-held (expanded) mucin layers of high free-volume. The illustrated scheme is adapted from References [22-24].

In a more simplistic representation, mucin networks can be visualized as multilayers of mucin glycoproteins. In the respiratory or gastrointestinal tract, the networks contain two distinctive zones, (1) a loosely adherent outer layers with an expanded free volume that are prone to easy removal; and (2) a denser, more intact, mucosal adherent inner layer [25-29]. The loosely held outer layers are formed via disulfide intermolecular bonding. While, the inner layers of mucin networks are self-organized from relatively longer mucin chains, whose hydrophobic domains firmly anchors it to the epithelial surface. Further, aided by complexation, they form a more robust, tight network [24].

Mucin network's structure and its rheology can be highly interdependent, which can be impacted by localized $\mathrm{pH}$ and ionic concentration. For instance, using gastric mucin, studies by Cao et al., (1999) [30], which was later supported by Hong et al., (2005) [20], have demonstrated that mucus undergoes $\mathrm{pH}$-dependent sol-gel transition, where at simulative gastric environment $(\mathrm{pH}<4)$, the glycoprotein chains possess an extended conformation as opposed to the random coil state. This chain reorientation favors the hydrophobic complexation between glycoprotein chains, causing the gelation of a viscous solution into a tight protective intestinal barrier. Apart from $\mathrm{pH}$, such conformational shifts can occur due to changes in ionic environment effecting from electrostatic charge interactions, 
causing swelling or shrinkage of bulk networks [30]. Hence, influenced by regional environmental conditions, the structural organization of natural mucin networks can differ regionally and temporally throughout the body. This structural property variation (e.g., pore size, viscosity) plays a critical role in its biofunctional behavior. As an example, human cervical mucus shows changes in its network structural organization based upon the phases of the menstrual cycle, impacting the spermatozoal transit $[31,32]$. It should be noted, this structural-biofunctional interdependence in mucin networks can be governed by the composition of the type of mucin, which in turn is associated with subjects health condition (healthy vs. diseased state). For instance, studies by Thornton and co-workers [33] have established that in respiratory mucin networks, its oligomeric mucin composition (MUC5AC, MUC5B) shows variation between diseased (e.g., cystic fibrosis, chronic obstructive pulmonary disease (COPD)) and healthy subjects.

The radius of gyration of high $M_{\mathrm{W}}$ natural mucin $(\sim 19,000-32,000 \mathrm{kDa})$ ranges from $\sim 190$ to $270 \mathrm{~nm}$. In a more detailed look, the mucin diameter can range from 3 to $10 \mathrm{~nm}$, and its length can span out from $100 \mathrm{~nm}$ to several microns [34]. For instance, studies by Round et al., (2002) [35] have shown that in ocular regions, the glycoproteins contour length distribution can extend up to $1500 \mathrm{~nm}[35,36]$. These glycoprotein chains self-organize forming networks, whose structural properties such as thickness and mesh size, can vary significantly both within and across different regions (inset Figure 2). For instance, in human gastrointestinal track, the mucin network thickness is found highly variable ranging between 50 to $450 \mu \mathrm{m}$ (see Figure 2 for thickness distribution in different mucosal surface) [37]. Likewise, the thickness variations can also be seen in different species, for instance Atuma et al., (2001) [25] measured the rat gastro-intestinal mucin network thickness. In their studies, the network thickness was quantified for both intact and loosely-bound mucin layers. Recent work by Ermund et al., (2013) [38], illustrated that in mouse models, the small intestine possesses only the loosely held mucin layers, thereby facilitating easier nutrient absorption. However, in large intestine, the mucus layers are thicker and contain both the loosely held and intact layers, where its inner bound layers functions to selectively block the bacterial access into epithelial surface. This exemplifies the interrelated structure-functional dependency in natural mucin structures.

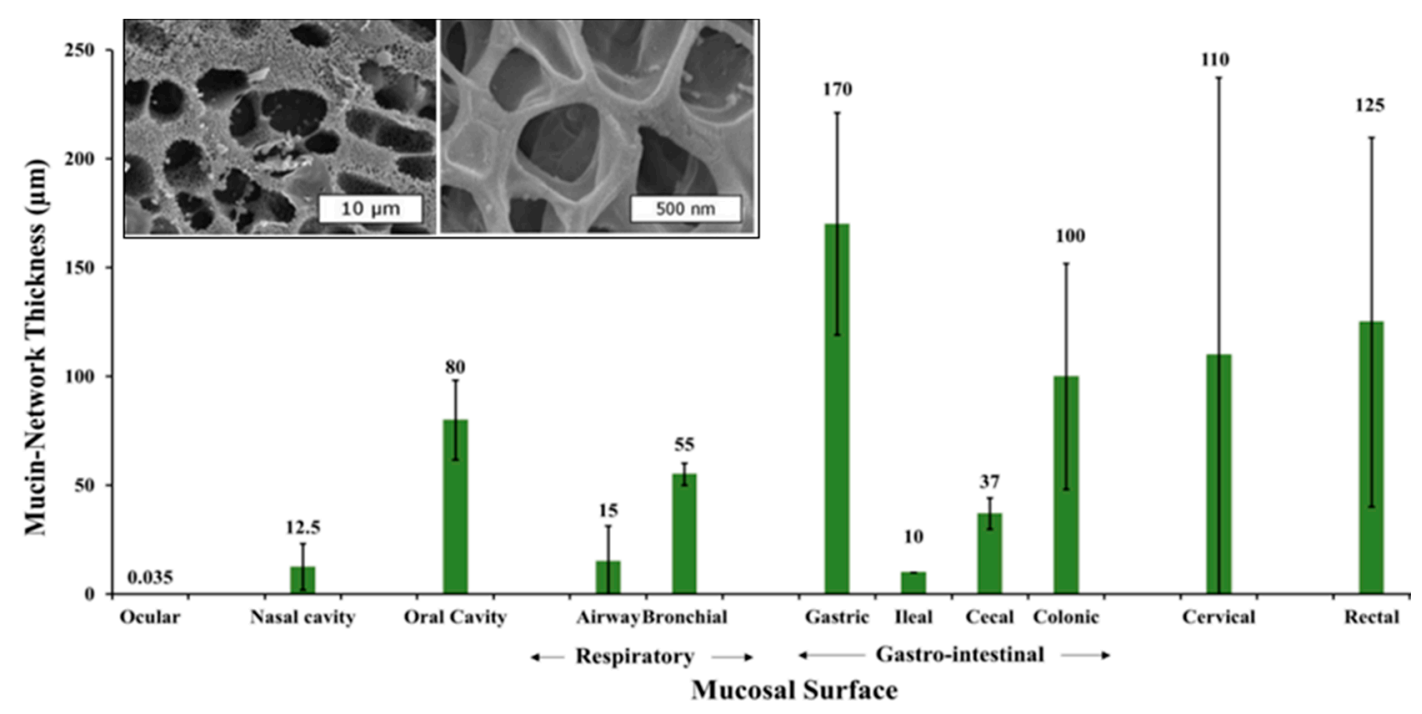

Figure 2. Mucin network thickness varies based upon its physiological location and role. Based on findings from References [39-41]. Inset figure shows cryo-SEM imaging of pulmonary mucin, demonstrating heterogeneous mesh size distribution. Reprinted with permission from Reference [42]. Copyright @ 2009 , National Academy of Sciences.

The thickness variations in mucin networks is highly dependent on their proximity to the secretory glands and other physical factors, such as breathing, mastication, and swallowing can also significantly affect [39]. For example, studies by Collins et al., (1987) [39] and Tinanoff et al., (1976) [43] have 
compared oral mucin thickness in adult and children (ranges $\sim 50-100 \mu \mathrm{m}$ ), and found it to be independent of variations in the total available surface area. However, relative to buccal soft tissue, the mucin thickness along enamel surfaces is significantly lower $(\sim 0.03-0.1 \mu \mathrm{m})$, suggesting variations along different regions.

The mucin structure can also possess a high degree of heterogeneity in its mesh size, both within and across different regions. For instance, study by Olmsted et al., (2001) [40] on human cervical mucins have suggested its pore size to range between 20 to $200 \mathrm{~nm}$. Similarly, Lai et al., (2011) in their work reported that in cervicovaginal regions, its mesh size can range between 50 to $1800 \mathrm{~nm}$ [44], while Matsui et al., (2006) [45] have reported that in tracheobronchial mucus, they range from 200 to $1000 \mathrm{~nm}$.

\section{Natural Mucin Network Function}

Mucin is almost ubiquitously presently in all biological systems. They line the mucosal epithelium in the ocular, nasal, buccal, respiratory, gastro-intestinal tract, vaginal and rectal regions. In general, mucin networks regulate bacterial adherence (aggregation and/or clearance), provide surface lubricity, retain moisture (through surface hydration), acts as a protective shield for the underlying mucosal surface, and allow for a selective permeability (e.g., oxygen transport, nutrients) (Figure 3) [4-7].

MUCIN PREVELANCE

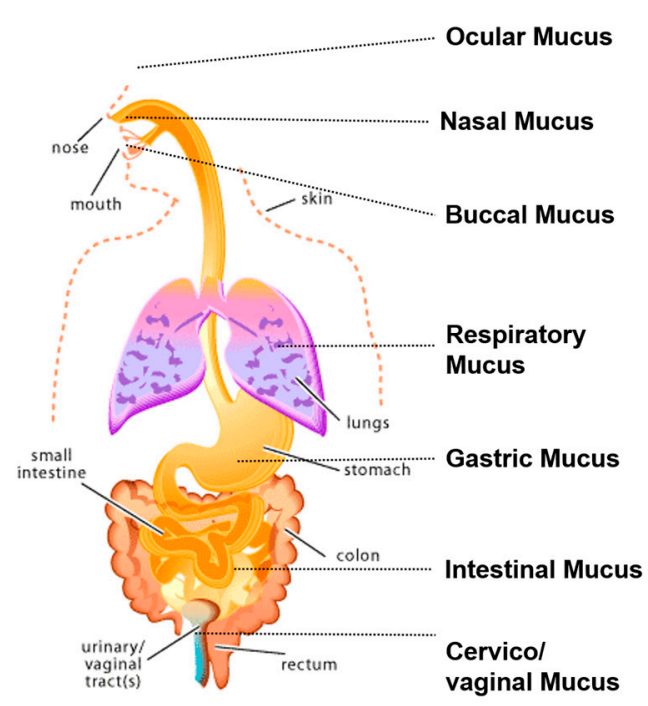

\section{KEY FUNCTION}

- Retains epithelial moisture (Tear film) Avoids dry eye

- Regulates bacteria/particulate removal

- Provides lubricity

- Surface lubricity/hydration/selective permeability

- Barrier protection (e.g. bacteria)

- Prevents tooth demineralization, dry mouth

- Air humidification (epithelial hydration)

- Mucociliary clearance Regulates bacteria/particulates removal

Shields from direct gastric juice exposure (gastric mucosal barrier)

Facilitates easier bolus passage

Mucin-probiotic association forms protective barrier

- Forming cervical mucus plug

- Selective permeability Hinders pathogens, regulates spermatozoa migration

Figure 3. Illustrative scheme highlighting mucin network prevalence and its key functional properties across different regions within human body. The respiratory-gastrointestinal figure outline was taken from Reference [46].

In eyes, the protective barrier is referred as the tear film (thickness $\sim 6-10 \mu \mathrm{m}$ ) [13], which is comprised of (1) an innermost ocular mucin coat that immediately surrounds the epithelial surface in protecting them; (2) an intermediate aqueous layer that is formed from soluble mucin components; and (3) an outermost oily layer. The function of the mucin layer in tear film is to help (1) regulate the stability of aqueous-oily layers [47]; (2) act as a barrier in protecting the underlying epithelial surface; and (3) aid in retaining epithelial moisture [47-49]. Interestingly, in subjects with contact lenses (e.g., silicone hydrogel lenses), upon prolonged wearing, these ocular mucin coats can roll up into spherical balls (mucin balls). Despite this change in morphology, these spherical balls do not appear to impact the visual responsiveness, cause discomfort, or contribute to bacterial invasion [50]. Some recent work has even suggested the potential role of mucus balls in obviating corneal infiltrative events (e.g., corneal inflammation), associated with contact lens wear [51].

In the buccal cavity, the mucin networks offer selective permeability (e.g., unhindered transport of solubilized molecules to taste receptors), and coupled with its barrier properties (e.g., lubrication, 
surface hydration and protection), helps regulate oral health. Clinically, with a lack of these functional properties, oral dryness can occur, (e.g., xerostomia) accompanied by painful inflammation. In United States, one to four million people suffers from Sjögren's syndrome (dry mouth \& dry eyes) and nearly $20 \%-30 \%$ of the people were affected by xerostomia with even more prevalence among senior and women [52-54]. This hyposalivation may be temporary among certain populations, but with patients undergoing treatment such as radiotherapy, they are at a high risk of developing an irrecoverable damage to salivary glands, causing permanent oral dryness. In xerostomic patients, there is an increased susceptibility to microbial colonization leading to oral infections (e.g., candidiasis) [52,54,55]. For instance, mucin contains antifungal peptides (e.g., histatins, MUC7 12-mer) [56-59], which play a key role in inhibiting candidiasis, a prevalent fungal infection that results from Candida albicans. Nearly $95 \%$ incidence rate of candidiasis was reported among patients with acquired immunodeficiency syndrome (AIDS) [60]. Wide clinical research were performed in an effort to understand the effects of oral salivary flow rate and/or its composition on pathogenesis of candidiasis. Their studies showed nearly $37 \%-40 \%$ reduction in oral salivary flow rate among HIV+ patients [60,61], and the antifungal mucin components in salivary compositions were also found significantly lower [58,62], culminating into a diseased condition.

Mucin networks, when extended over enamel surfaces, are referred to as acquired enamel pellicle. When the tooth surface is exposed to acidic conditions, the pellicle layer aids in reducing enamel-demineralization [19], Mechanistically, the mucin networks are formed through higher ordered complexation-aggregation deposition process as that of acquired pellicles, independent of the substrate-interfacial site (enamel or buccal surface) or tissue hardness (soft or hard oral tissue).

In the respiratory tract, the mucin network regulates bacterial and particulate removal through mucociliary clearance. During inhalation, the respiratory mucin coats provide air humidification and helps maintaining epithelial hydration [63]. In regions of the stomach and duodenum, the adherent mucin layer acts as a shield, protecting the epithelium from direct gastric juice exposure (e.g., hydrochloric acid, pepsin), commonly referred as gastric mucosal barrier (GMB) [64]. The barrier property in GMB is due to the formation of a mucin-bicarbonate barrier, where the bicarbonate secretions occur from the mucosal surface. This barrier creates a $\mathrm{pH}$ gradient across luminal (low $\mathrm{pH}$ ) to epithelial side (high $\mathrm{pH}$ ), protecting the epithelial surface $[65,66]$. Also, the mucin networks are selectively permeable, allowing for cell migration and repair of damaged tissue. The mucin network creates a micro-environment for cellular components (e.g., cells, plasma proteins), forming a mucoid cap via its scaffold-like structures, thus promotes revascularization $[37,41]$.

In the gastrointestinal tract, mucin's lubricative effect facilitates an easier passage of the food bolus through the intestine. In addition, mucin serves as a matrix that promotes adherence of probiotic strains (e.g., lactobacilli, bifidobacterium) [67-69]. The synergistic probiotic-mucin association helps form mucosal barriers, protecting against harmful microbial infections (e.g., bacterial, viral) [44,67,70-72]. Any compromise in the barrier integrity could alter food digestion, render epithelium vulnerable to enteric pathogens and can cause intestinal inflammation [68,73].

In the cervix, the mucin network functions like a selective permeable layer, commonly the cervical mucus plug. The mucus plug hinders transport of bacteria and viruses (e.g., Lactobacillus spp., herpes simplex virus $[74,75]$ ) in the reproductive tract, while preferentially aiding the motility of spermatozoal migration (Figure 4). Any irregularities in function of the cervical mucin networks can even cause infertility [76,77]. A recent study has demonstrated the protective barrier effect of human cervicovaginal mucus in impeding HIV type1 transport to underlying epithelium [78,79]. 
a)

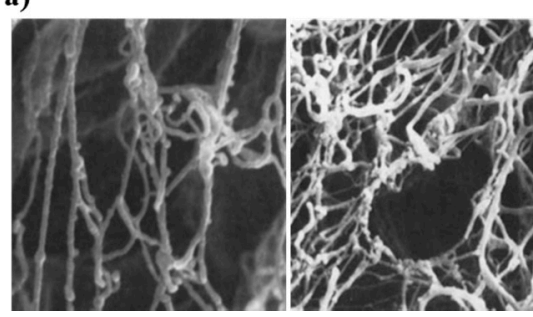

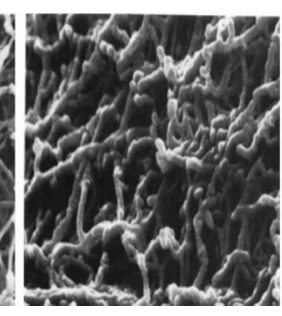

b)

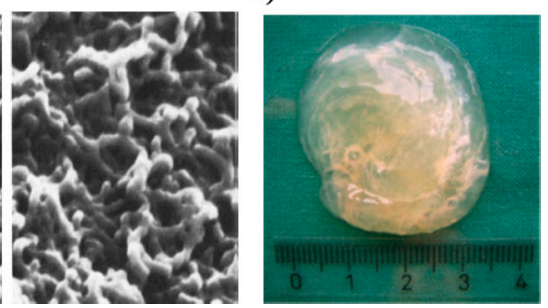

Figure 4. (Left) CMP at different stages of pregnancy (a) (left to right) at 20th day, 5 weeks, 2-1/2 months, and last week of pregnancy. Cervical mucin network density increases progressively during the gestation period, and forms a more compact interconnected fibrillar networks. The mucus functions as a selectively permeable plug that blocks pathogens and allows nutrients and growth factor to transport. Reprinted with permission from [80]. Copyright (c) 2011, John Wiley \& Sons, Inc.; (b) Figure showing bulk structure of cervical mucus plug discharged during labor. Reprinted with permission from [77]. Copyright @ 2010, John Wiley \& Sons, Inc.

\subsection{Mucin Network's Role in Microbial Regulation}

Mucins, via their adhesion tendency, play a critical role in microbial capture across different regions, which helps regulate microbial growth and maintain health. Human body is rich in diverse variety of bacterial flora. For instance, it is estimated in humans that nearly 500 species of bacteria populate the oral cavity (e.g., Streptococcus, Veillonella) [81-84]. In the epithelial surface, the loosely held mucin outer layers can function as a sacrificial trap in bacterial adherence, which coupled with oral salivary flow mechanism can help regulate the microbial clearance [8]. However, since the innermost mucin layers forms a robust tight barrier, they function as a protective shield, preventing bacterial transport to the underlying epithelia. For instance, in the gastrointestinal tract, the mucin barriers shields the epithelium from polymicrobial infection. This barrier function, if compromised, can lead to chronic inflammation, causing ulcerative colitis [68]. The mucin bacteria adherence mechanism can be more readily understood by studying the bacterial growth process over tooth surfaces. The mucin pellicles promote bacterial adherence, yet also helps protect the tooth from acid demineralization effects [85]. Interestingly, if the adherence process is left unregulated, this can result in serious complications, including dental caries and periodontal disease or vocal disorder due to laryngeal mucus [86], cystic fibrosis (CF), COPD or bronchial asthma in pulmonary tracts [87,88]. Study by Matsui et al., (2005) [89] have suggested the due to unregulated thick mucus secretion from cystic fibrosis, there is a reduced migration ability of neutrophils across the bacterial trapped mucus barrier, thereby compromises neutrophil's bacterial killing ability and contributes to airway infections.

Extensive studies were performed to understand the bacterial distribution among different mucosal regions, and how their diversity changes with pathologic conditions. For instance, Aas et al., (2005) studied the bacterial flora diversity in different regions (hard/soft tissues) of the oral cavity, and found that there is significant difference in bacteria flora distribution between diseased and healthy patients [83]. The adherence tendency of mucin also helps form a desirable physical barrier that can hinder permeation of virus. For instance, Lai et al., (2009) [74] found that in cervicovaginal mucus, the transport rate of herpes simplex virus $(\sim 180 \mathrm{~nm})$ was atleast 8000 fold lesser than the non-mucoadhesive carboxyl-modified polystyrene particles ( 200 nm), illustrating mucins less emphasized role as protective shield.

The mucin-microbial capture mechanism can be attributed to the specific surface receptors available in the microbes (e.g., adhesins such as lectins and enzymes). Driven through non-covalent molecular forces such as charge and hydrophobicity (mucoadhesive effect) [2,90], the microbial receptors specifically bind to the oligosaccharide chains available in mucin glycoproteins (e.g., oral pellicle) [2,83,91-93]. During the mucoadherence process, the favorable molecular conformation of glycoprotein chains facilitates for an improved microbial capture. For instance, mucins with high 
proline content, due to its hydrophobic nature, easily anchors to the epithelial surface, which allows oligosaccharide side chains to orient toward exterior apical side, aiding adherence [8,94,95]. Apart from adhesive forces, the screening effect emanating from the size differences between network mesh and microbes can also play an important role, impacting microbial accessibility to the underlying surface.

\section{Mucin Networks as Physical Permeation Barrier for Biofunctional Molecules}

In general, mucin networks allow for selective permeability. Mucin glycoprotein impact the diffusional properties of agents through steric obstruction or adhesive interactions (e.g., hydrogen bonding, hydrophobic and/or ionic interactions) or size exclude based on its mesh spacing (Figure 5). Such reduced permeability of biofunctional molecules (e.g., drugs carriers such as nanoparticles) can have an effect on therapeutic bioavailability in the underlying mucosal epithelium. Efforts to minimize nanoparticle interactions (mucoadherence) with mucin barriers have received significant attention, due to the recent advancements in the field of nanomedicine. The hindered transport rate in many of the nanoparticle based systems can emanate from adhesive interactions with the mucin chains [96]. Studies have well-articulated that nanoparticle charge properties can play an important role during the trans-mucus permeation $[97,98]$. In improving mucopenetration, a near neutral charged nanoparticle was preferred (Coaker (2014) [97]). Such charge tendency is not limited only to nanoparticle based systems. Recently, Ribbeck and co-workers (2013) [99] have demonstrated a reduced permeability rate for both cationic and anionic peptide transport across mucin barrier. In their study, apart from net charge, the spatial charge distribution of the transport molecule and ionic environment of mucin barrier were found to play a crucial role in affecting the transport kinetics within mucin.

Commonly, permeation based studies were performed using FRAP (fluorescence recovery after photobleaching), or particle tracking technique such as single/multiple particle tracking, time-resolved confocal microscopy or fluorescence correlation spectroscopy (FCS) [79]. For instance, in gastrointestinal mucin networks, Crater et al., (2010) [98] have demonstrated that a significantly reduced mobility can be observed among polystyrene nanoparticles with different surface charge modifications (amine, cationic and sulfate) via multiple particle tracking measurements. Mucin networks form a protective shield, which hampers mobility of most the metal nanoparticles (e.g., cerium oxide, Zirconium dioxide) and can immobilize carbon nanotubes (Jachak et al., 2012) [96].

In improving mucopenetration, the use of PEGylated stealth nanocarriers has been attempted. Such PEGylation approaches are commonly utilized in improving drug circulation time from reduced opsonization effects. Due to such added prevalence, studies pertaining to transport behavior of PEGylated nanocarriers across mucin barrier have received considerable attention in recent years. For example, Wang et al., (2008) [100] have shown that among PEGylated nanocarriers, the extent of PEG surface coverage and its molecular chain length can significantly impact the nanoparticle interpenetration through cervical mucus. By increasing the PEG chain length, there is an increased probability for its entanglement with mucin glycoprotein chains, thereby can entrap/reduce the carrier transport rate. Also, even with lower $M_{\mathrm{w}}$ PEGylation, by increasing the net negative charge or reducing the degree of PEG surface coverage can result in a hampered diffusional rate [100].

In general, the small molecule proteins like bovine serum albumin and antibodies (e.g., immunoglobulins IgG, IgA and IgM) [101] possess weak interaction with glycoproteins chains, and owing to its considerable size difference with mucin mesh, their transport rate were only weakly hindered $[40,101]$. Due to similar size-based effects, smaller viruses can diffuse less hindered through mucin barriers. However, with antibody (Ab) bound pathogens (e.g., Ab-virus such as HIV [102], HSV [103]), the permeation can be hampered from increased adhesion effects from multiple low affinity antibody-mucin interactions [104]. 


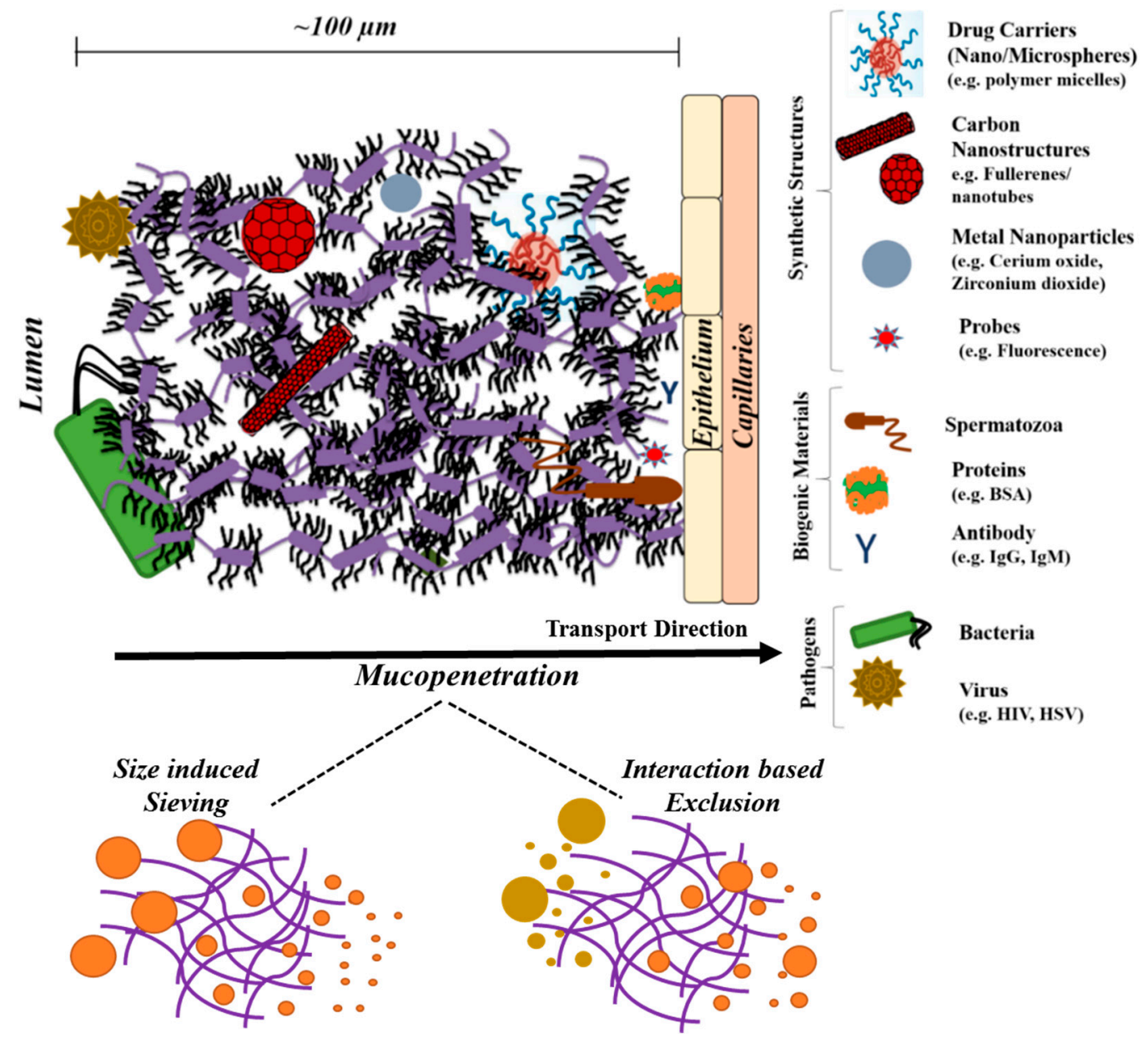

Figure 5. Schematic of mucin network's (cervical region) ability to impact transport properties of various biogenic materials, synthetic structures or pathogens across its physical barrier. Figure also illustrates the mucopenetration effects, which can arise as a result of differences in network mesh size, or its adhesive interactions with transport molecules. Figure was adapted from References $[105,106]$.

\section{Critical Role of Mucin Network in Impacting Diverse Bioapplications}

\subsection{In Designing Drug Delivery Systems}

Traditionally mucin is viewed as a barrier to overcome for drug delivery applications. For instance, mucin as a physical barrier can limit drug permeation, and efforts to improve the drug carrier stealth tendency by varying its physical (e.g., size) or chemical (e.g., However, by understanding the mucin network functional properties, it proposes wide potential in variety of bio applications.

For instance, the mucin's adherence tendency can be used beneficially in designing drug delivery systems (DDS) such as drug encapsulated microsphere/nanoparticle formulations, or mucoadhesive gels/tablets/patches. Recent findings [34,107] suggest that mucin networks can immobilize most of nanomaterials (e.g., polymeric nanoparticles) or alter its particulate transport via adhesive and steric forces. For gastro-intestinal (GI) drug delivery, such mucoadhesive effects can be used to enhance the drug transit time across GI tract. The use of mucoadhesive polymers (e.g., chitosan, hydroxypropylmethylcellulose (HPMC), poly(vinyl pyrrolidone) (PVP), poly(ethylene glycol), carboxymethylcellulose (CMC)) [108-110] has been shown to increase the residence time, thereby improving the efficacy of drug adsorption.[34,111-115] Araújo et al., (2014) [115] have demonstrated that in chitosan coated nanocarriers (e.g., poly(lactide-co-glycolide), solid lipid nanoparticles and porous silicon), a more sustained release of payload (e.g., glucagon like peptide-1) 
with enhanced bioavailability resulted from its mucoadherent tendency. Thus, these DDS can be utilized in ocular [116-119], buccal [120-123], nasal [124-127], pulmonary [128-131], vaginal [132-136], or rectal [137-140] delivery, for eliciting a therapeutic effect either locally or systemically $[13,114,141]$.

\subsection{Mucin as a Bio-Functional Coat}

Recently, mucin has been studied for its potential as a functional coat to inhibit biofouling and promote cell pattering. For instance, Thasneem et al., (2013) [142] have shown that mucylated nanocarriers (e.g., polylactic-co-glycolic acid) possess reduced opsonization effect with promising haemo- and cyto-compatibility. Mucin also possesses interesting potential when utilized as an implant coating (e.g., vascular grafts), offering excellent surface lubricity and haemocompatibility. For example, Janairo et al., (2014) [143] demonstrated in rat models that implants containing covalently grafted mucin layers can effectively inhibit platelet adhesion and prevent thrombosis. In their studies, the untreated vascular grafts showed higher platelet adherence $\left(\sim 210\right.$ platelets $\left./ \mathrm{cm}^{2}\right)$, however upon mucin incorporation the surfaces exhibited significantly reduced platelet adhesion $\left(<60\right.$ platelets $\left./ \mathrm{cm}^{2}\right)$. The mucins can be included either as a passive adsorption $\left(\sim 60\right.$ platelets $\left./ \mathrm{cm}^{2}\right)$ or can be covalently bound (PEGylated mucin) $\left(<10\right.$ platelets $\left./ \mathrm{cm}^{2}\right)$ to those implant surfaces.

Mucin coatings can also reduce protein and neutrophil adherence onto biomaterial substrate like polyethylene terephthalate, which can be beneficially used in reducing biomaterial mediated inflammatory host response [144]. Similarly, studies by Shi et al., (2000) [145] have demonstrated mucin's ability to improve surface wettability and inhibit bacterial adhesion over variety of synthetic surfaces such as polystyrene, polyurethane, silicone, and poly(methylmethacrylate). Such microbial inhibitory and lubricative function provides exciting opportunities for its use as coatings in various biomedical devices (e.g., stents, catheters), that require high surface lubricity and low friction.

In a more recent work, Crouzier et al., (2013) [146] have demonstrated that mucin can serve as an elegant cell-repulsive biopolymeric coat, which can be used in regulating adherence of different mammalian cell types (e.g., epithelial cells, fibroblasts, and myoblasts. While, Johnson et al., (2009) [147], in their work have functionalized peptide microtubes with mucin glycoproteins, which demonstrated improved cell adhesive property (normal rat kidney cells) and allowed for cell spreading along its aggregated microtubular structures. Such mucylation of micro- or nanotubes with drug encapsulation can be used for targeted payload delivery and improving the drug bioavailability. As a surface modifier, Bertozzi and co-workers (2004) [148] have demonstrated that glycosylated biopolymers grafted to carbon nanotubes (CNTs) mimics the natural mucin arrangements present along the cell surface (Figure 6). Such modified CNTs can inhibit non-specific protein adsorption.

Mucin possesses an interesting complexation capability with hydrophobic molecules, which can improve its aqueous solubility. Drug et al., (2010) [149] in their work demonstrated mucin (bovine submaxillary mucin, -BSM) was able to complex with polyaromatic hydrocarbons (e.g., Benzo[a]pyrene). These mucin-complexed molecules demonstrated an improved bioavailability and membrane-penetration ability. Likewise, Gozin and co-workers (2010) [150] demonstrated that bovine submaxillary mucin can stabilize dispersions of hydrophobic nanocolloids such as C60 fullerene, inorganic fullerene-like gastro-intestinal (IF-WS ${ }_{2}$ ) and multi-walled carbon nanotubes (MWNT) in aqueous solution. 


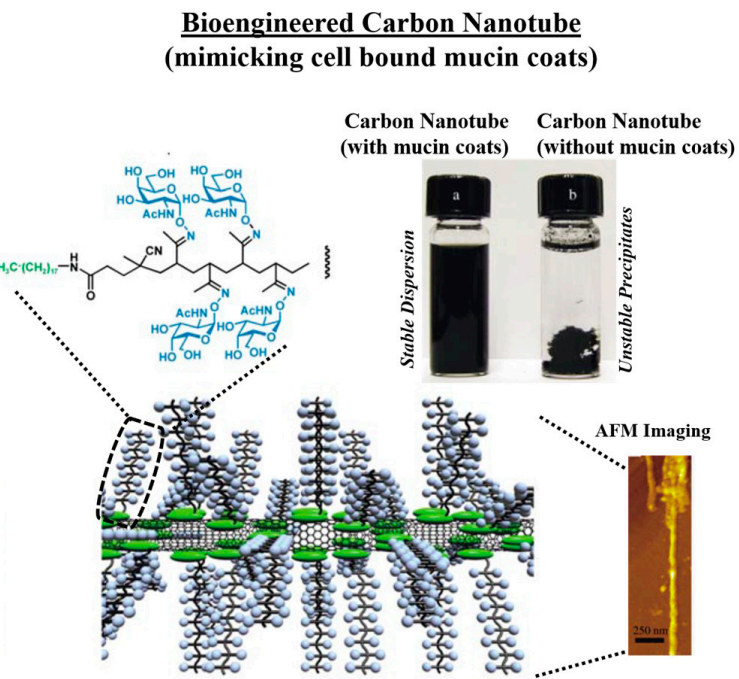

Figure 6. A comparison of native cell bound mucin coats with biomimetic carbon nanotubes possessing cell bound mucin coats. The bioengineered carbon nanotubes mimics the native cell bound mucin functional property, and can be used in preventing non-specific protein binding (antibiofouling), or immobilizing specific functional molecules to CNT via specific biomolecular recognition with mucin chains, or as coatings for developing stable dispersions. Reprinted with permission from Reference [148]. Copyright (C) 2004, Wiley-VCH Verlag GmbH \& Co. KGaA, Weinheim.

\subsection{Mucin in Drug Delivery and Tissue Engineering Applications}

The critical role of mucin as a functional scaffold is relatively less emphasized in natural settings. For instance, studies have demonstrated that mucin can associate with carbohydrate-binding proteins like selectin and lectin [151-154]. While, during the early phases of pregnancy (peri-implantation period), cervical mucus scaffolds can impact adherence of blastocysts possessing L-selectin rich outer walls, and thereby critically affect embryo attachment to the uterus [155].

Inspired by such capable mucin-protein interactions, recent studies have demonstrated the ability to synthetically develop versatile multilayered structures/scaffolds via layer-by-layer (LBL) approach, for potential drug delivery and regenerative applications. For example, Crouzier et al., (2012) [156] and Polak et al., (2014) [157] have shown that structurally robust multilayers can be fabricated from mucin sugar-lectin interactions. Mucin glycoproteins were rich in sugars moieties such as sialic acid and $\mathrm{N}$-acteyl-D-glucosamine $[157,158]$, which are specific towards lectin moieties. The multilayers formed via those specific linkages are highly stable, and can remain unaffected by effects of salt or $\mathrm{pH}$ shifts [156]. Utilizing the specific mucin-lectin linkages, previously studies have been demonstrated in drug carriers (e.g., microspheres) systems, where particulates can be surface functionalized with concanavalin-A (lectin) in developing a targeted drug delivery systems $[159,160]$.

Apart from carbohydrate-protein interactions, mucin-based multilayers can also be developed via conventional charged based interactions. Mucin glycoproteins possess net negative charge, hence utilizing its ionic tendency, mucin can be self-assembled along with a positively charged polymer (e.g., poly(diallyldimethylammonium chloride) [161], chitosan [162]) using LBL deposition technique. Interestingly, Wang et al., (2012) [161] in their recent work used pig gastric mucin (PGM) and poly(acrylamide-co-3-acryl-amidophenylboronic acid) (P(AAm-AAPBA)) in developing a stimuli responsive multilayered scaffold. The self-assembling process was driven by formation of boronate ester linkages between polyols in PGM with boronic acid units in P(AAm-AAPBA). Those linkages are reversible under glucose environment, and the multilayers formed can be selectively disassembled and utilized for stimuli induced drug release $[161,163,164]$.

In regenerative medicine applications, mucin-containing artificial saliva (e.g., Saliva Orthana ${ }^{\circledR}$ ) can be used as an effective salivary substitute. Various clinical studies are performed and have corroborated 
mucin's beneficial role in developing buccal formulations [165-168]. Mucins through its hydrated topical coat helps alleviate oral mucosal complications such as xerostomia and mucositis $[169,170]$. For instance, study by Davies et al. (1998) [171], showed nearly 73\% of xerostomic patients showed improvement through use of mucin based salivary substitutes, and work by Sweeney et al., (1997) [172], from their clinical trials suggested excellent patient compliance, when administered as an oral spray.

In a recent work from Duffy et al., (2015) [173], they used methacrylated mucin to form a covalently crosslinked hydrogel. These mucin-based scaffolds are capable of loading both hydrophobic and hydrophobic drugs, via its intrinsically diverse chemical nature (hydrophilicity) and its mucoadhesive interactions (e.g., hydrophobic, electrostatic forces), and was demonstrated for its ability to offer a sustained drug release.

\section{In Modeling Importance and Need for Rigorous Characterization}

In drug delivery applications, the mucin coats and its underlying epithelium were the main contributors to reducing drug permeability across mucosa surfaces [34,174,175]. In an effort to improve the drug permeability across the mucosal barrier, there is a growing interest among researchers to understand the network properties (physical and chemical behavior). In understanding mucin network barrier properties, Gniewek et al., (2012) [176] used a coarse-grained model (polymer lattice model) to study nanoparticle transport through mucin networks. Their results suggested that the innermost layers in mucin networks are firmly held and play a critical role in hindering the particle diffusion. However, due to the mucin network formation complexity, it poses a significant challenge to understand its interrelated structural and chemical properties on its bulk network behavior [177].

Much of the recent work have centered on studying the effect of nanoparticle physicochemical characteristics (e.g., nanoparticle size [178], surface chemistry [40,179,180], and PEGylation [178]) on the transport properties across mucin networks. For example, Norris et al., (1996) [179], used polystyrene nanoparticles in studying the effect of particle size, surface hydrophobicity and charge properties on transport across gastrointestinal mucus. Their study suggested that there is a significant drop in permeability when particle diameter reaches $\sim 300 \mathrm{~nm}$ (permeability $\sim 5 \times 10^{-5} \mathrm{~cm} / \mathrm{min}$ ), and a more gradual drop in its transport rate for concomitant increase in particulate diameter till $\sim 500 \mathrm{~nm}$ (permeability $\sim 0.7 \times 10^{-5} \mathrm{~cm} / \mathrm{min}$ ). Additionally, their study suggested that compared to $\zeta$-charge potential the surface hydrophobicity of particle can play a critical role in hindering the particle translocation. Thus, by increasing the relative hydrophilicity a lesser transport resistance for particle migration was expected.

Despite such significant efforts, the bulk network behavior remains unclear and in some instances, contradictory. For instance, Lai et al., (2007) [178] studied the transport of PEGylated nanoparticle across mucin networks, using NPs of different diameters. To obviate PEG interpenetration with mucin glycoprotein chains, the study utilized relatively lower $M_{\mathrm{W}}$ PEG chains of $\sim 2 \mathrm{kDa}$ and their results showed an improved transport across mucin network in comparison with uncoated particulates $[105,178]$. Interestingly, among PEGylated nanoparticles the larger particulates demonstrated a more rapid transport than the smaller particles. In particles with larger diameter $\sim 200$, $\sim 500 \mathrm{~nm}$, diffusion was only 6 and 4 -fold lower in cervical mucus than that of pure water, respectively. However, for smaller particles (diameter $\sim 100 \mathrm{~nm}$ ), the diffusional rate was nearly 200 -fold lower. This was particularly surprising as the mesh size in the mucin networks was previously reported to be in the range of $10-200 \mathrm{~nm}[40,101,178]$.

The formation of mucin networks is a dynamic process, constantly subjected to removal and reformation effects. Thus, a thorough understanding of mucin network properties, its physical and chemical understanding can play a critical role in predicting bulk interaction with drug (or drug nanocarrier) formulations. Such approaches help formulation scientists in designing drugs that allows for a rapid mucin clearance and improved epithelial availability. 


\section{Polymer Network as Synthetic Mucin Analog}

\subsection{Developing Polymer-Based Biofunctional Structures}

Developing functional polymeric mimics has received wide attention owing to its application in the areas of regenerative medicine and tissue engineering applications, for instance, the use of hydrophilic three-dimensional hydrogel scaffoldings. However, the polymeric structures, when it replicates the functional and/or structural characteristics observable in nature, becomes a biomimetic analog. Such approaches are not confined only to mimicking complex biomolecules (e.g., protein mimetic polymers, peptide mimics from amino acid conjugated dendrimers) [181,182], but can be developed to translate into a more complex functional analog, such as synthetic mucin networks.

The use of polymer-based biomaterials offers tremendous flexibility, due to its ease in incorporating modifications in its structural, chemical and biofunctional properties, tailored towards a specific application. For instance, through recent advances in polymer synthesis (e.g., atomic-transfer radical polymerization), the polymeric chemical properties can be easily tailored. This in combination with versatile material fabrication approaches (e.g., Layer-by-layer, electrospinning), can be used in forming novel functional structures [183-185].

The polymeric building blocks (e.g., di/tri-block copolymers) can also be driven by various molecular interactions such as ionic, hydrophobic/hydrophilic, van der Waals, hydrogen bonding, physical factors (e.g., shape) or micro-phase separation, and can self-assemble to form a more complex architecture [186,187]. In biological applications, such polymeric self-assembled nanostructures are well known for their ability to be biomimic. For instance, inspired by amphiphilic phospholipid bilayers, a considerable amount of interest has been generated in lipid self-assembly and theformation of liposomes [188]. While, in polymeric diblock systems, spherical vesicles (e.g., polymersomes) are comparable to virus capsids [188] and filomicelles are suggested for its structural relevance to filamentous phage [189]. These polymeric structures are derived from directed self-assembly that result from the dissimilar chemical nature of its building blocks. Conceptually, the self-assembly process is analogous to the formation dynamics observable in lipid bilayers, containing distinct hydrophilic head and hydrophobic tail region. These synthetic polymeric structures are well known for their potential as a nano-drug carrier system. For instance, the filamentous micelles possess relatively higher structural aspect ratio than the spherical micellar systems. As a drug carrier, filomicelles exhibited a higher circulation time than the conventional drug delivery systems (DDS).[190] Studies by various researchers (Dalhaimer et al., (2004) [191,192], Discher et al., (2005) [193], Geng et al., (2007) [194], and Shuvaev et al., (2011) [195]) have extensively demonstrated that these filomicelles can be decorated with bio-specific functional moiety (e.g., biotin, antibody) and applied for improving targeting and payload delivery. In a recent study, Pal et al., (2012) [196] used block copolymers of polystyrene- $b$-poly(4-vinylpyridine) (PS- $b$-P4VP) and self-assembled into a hairy nanofibers. These fibrous aggregates were utilized as a structural template for loading gold nanoparticle to form a hybrid metal-polymer construct [196].

\subsection{Polymeric Network: Role as a Synthetic Mucin Analog}

In developing a polymer based synthetic mucin model, Mahalingam et al., (2011) [197] used a stimuli $(\mathrm{pH})$ responsive in situ polymeric gels as a synthetic cervicovaginal mucin-mimic. Their study used cross-linkable phenylboronate-salicylhydroxamate based polymeric systems to form networks with increasing crosslinking density from vaginal to seminal $\mathrm{pH}$ range ( 4.0 to 7.5). The affinity (covalent) paring between boronic acid groups in phenylboronic acid with cis-diols allows for reversible condensation that is sensitive to $\mathrm{pH}$ changes, allowing for a facile sol-gel rheological transition [198-200]. For practical applications, as a cervical coat, in response to seminal fluid, the polymer systems were able to reversibly change from a loosely held viscoelastic to a more robust tighter network. At $\mathrm{pH}>4.8$, owing to decreased polymeric network mesh size, a significantly hindered virion transport rate was observed (Diffusion coefficient (Virions) $\sim 1.60 \times 10^{-4} \mu^{2} / \mathrm{s}$ at $\mathrm{pH} 4.8$ ) that was at least one order of magnitude lower in 
comparison to its transport rate at lower $\mathrm{pH}$. Similar mechanism can be utilized in impacting the migration of macrophages, where in the control placebo gels nearly $250 \mu \mathrm{m}$ transport of the cell was observed, whereas macrophage diffusion through the custom-developed polymeric gels showed no distinguishable movement. Hence, these synthetic gels can serve as a diffusional barrier to effectively block migration of biogenics like macrophages or inhibit transport of sexually transmittable pathogens like HIV present in the semen. Such polymeric systems apart from biomimetic potential, also provides exciting prospect as a delivery matrix for a localized drug release.

Similarly, Khutoryanskiy and co-workers (2015) [201], have demonstrated the ability to artificially recreate the mucin's mucoadherent tendency over glass substrates via formation and use of glycopolymer based hydrogels (Figure 7). The modified surfaces exhibited similar mucoadherent tendency as those found in ex vivo animal models. This was demonstrated in their work, through retention of mucoadhesive biopolymers such as chitosan and pectin in the cross-linked hydrogels. Thereby, such approach can be utilized as model framework for studying the mucoadhesive or biological responses (e.g., mucus bacterial capture) that emanates from membrane-bound mucin.

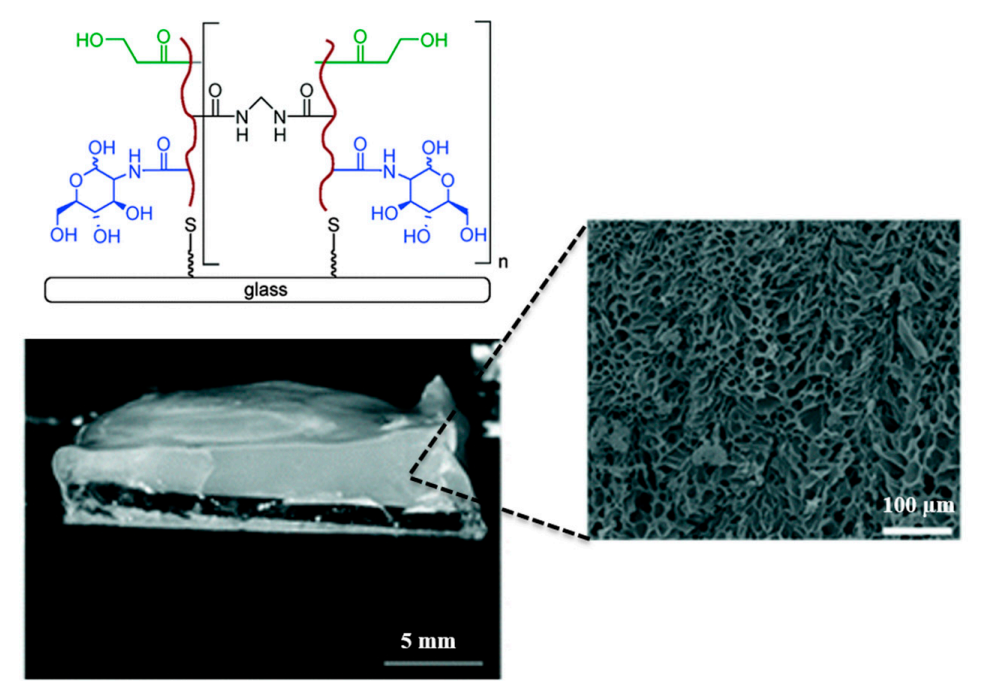

Figure 7. Glass-bound glycopolymer based hydrogels used as a model mucin network mimics in recreating the mucosal surface interfacial property. Scanning electron micrographs clearly shows highly porous structure of the hydrogels, these structures mimics membrane-bound mucin networks that were formed from glycoprotein chains. Reprinted with permission from Reference [201]. Copyright (c) 2015, The Royal Society of Chemistry.

Bertozzi et al. [202,203] in an attempt to mimick membrane-bound mucin glycoproteins, synthesized mucin mimetic polymers. Their study utilized polymers such as methyl vinyl ketone, isopropenyl methyl ketone and $\mathrm{N}$-[3-(dimethylamino)propyl]-acryl-amide (DAPA), decorated with aminooxy glycans ( $\alpha$-linked $N$-acetylgalactosamine (GalNAc) residues) and additionally end-functionalized with hydrophobic tail groups (e.g., cholesterol, phospholipids, and pyrene). The custom-synthesized synthetic glycopolymers mimicked the rod-like conformation as observed in the natural mucins, and was demonstrated for its ability to remain firmly bound to the supported lipid bilayer due to their hydrophobic anchors. More importantly, their work demonstrated the ability of cell-bound mucins to bind to carbohydrate-specific proteins such as lectin, suggesting molecular specificity and its biomimetic tendency similar to natural mucin. Based on these results, the concept was extended to develop glycopolymer based microarray platforms [203-205]. A dual end-functionalized mucin glycopolymers was used, which contain surface anchors tethered to one end and a fluorophore functionalized onto the second terminal. These new classes of glycopolymer were microcontact printed onto azide-functionalized microarray chips, and can be used in probing glycan specific associations (e.g., glycan-specific binding proteins such as agglutinin) [204]. 
In a recently published study $[15,84,206]$, it was demonstrated that a controlled layer-by-layer (LBL) deposition of pre-assembled filomicelles crosslinked via biotin-streptavidin affinity interactions, can create a synthetic mucin mimic (Figure 8). In forming synthetic model, PEG-PLA based diblock copolymers were used in forming drug encapsulated polymeric micelles of different shapes (spherical vs. filamentous). Structurally, the filomicelles are comparable to natural mucin glycoproteins, due to their high aspect ratio (Figure $8 \mathrm{~b}$ ). Hence, upon surface LBL deposition, these filamentous structures self-organized to form a complex intertwined nanoporous mesh-like structure, resembling natural mucin in its network morphology and mesh size (Figure 8c,e). Interestingly, it was found that the ability to grow into a fused-micelle network is greatly enhanced, by utilizing nanostructures with higher length to diameter aspect ratio like the filamentous micelles as opposed to spherical micelles.

a)

a)

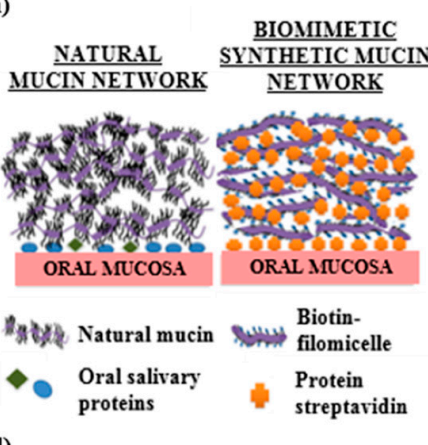

d)

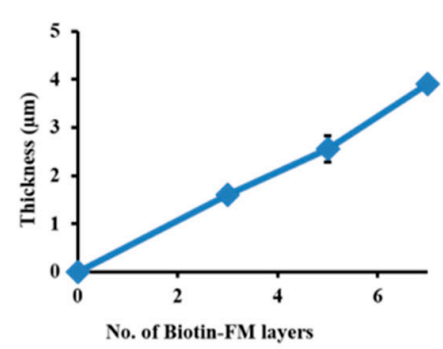

b)

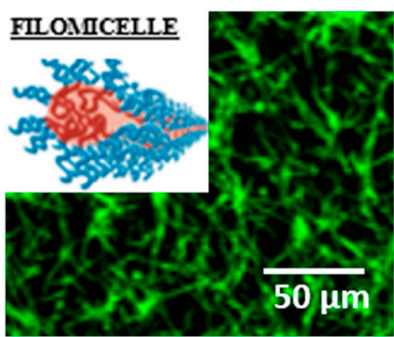

e)

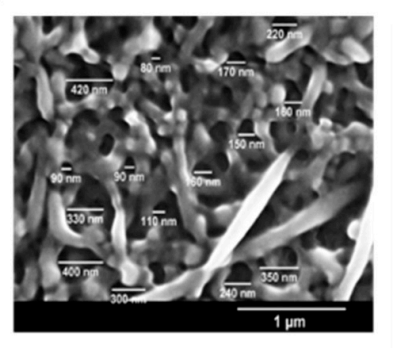

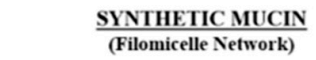

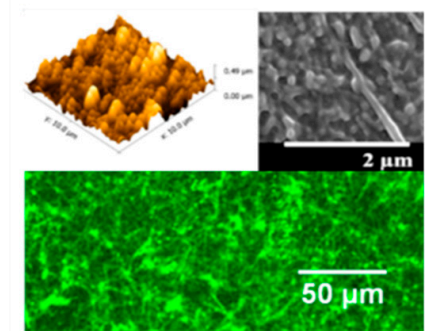

f)

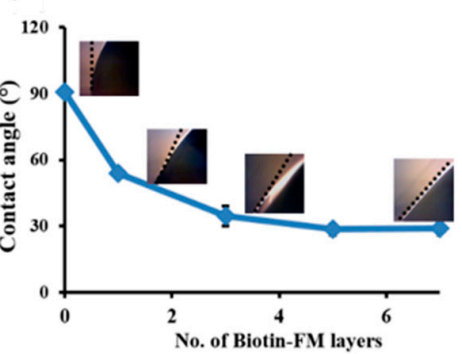

Figure 8. Synthetically derived mucin mimetic system formed from controlled Layer-by-layer (LBL) deposition of polymeric filomicelle, and its structural and functional relevance to natural mucin networks. (a) Overall simplified scheme showing natural mucin networks and biomimetic synthetic counterpart (filomicelle networks); (b) Fluorescence microscopic visualization of curcumin encapsulated biotinylated filomicelle. Similar to glycoprotein chains in natural systems, the filamentous micelles forms key building block in formation of synthetic networks; (c) Morphological relevance of natural mucin structures with synthetic mucin networks formed from filomicelle LBL depositions; (d) Controlled thickness growth in synthetic mucin networks can be achieved, by adjusting the number of LBL depositions. Figure shows during filomicelle network, where even with relatively lesser no. of micelle LBL additions ( 7), network with significant barrier thickness ( $\sim \mathrm{um})$ is achieved; (e) Filomicelle networks mimicked the nanoporous mesh size (average range $~ 110-340 \mathrm{~nm}$ ) observable in the natural mucin; (f) Synthetic mucin networks formed from PEG-based diblock copolymers displayed excellent surface hydration tendency. With synthetic mucin network depositions, the hydrophobic polystyrene (model synthetic interface) translated into a more hydrophilic, hydrating surface, this can be observed with lowering of contact angle from gonimetry study. Reprinted with permission from Reference [84] (Copyright 2015, Wiley-VCH Verlag GmbH \& Co. KGaA, Weinheim), and [15] (Copyright (C) 2014, American Chemical Society).

The filomicelle network barrier thickness can be increased with a relatively fewer number of LBL deposition cycles (Figure 8d), as opposed to conventional polyelectrolyte based multilayered systems. This approach is highly modular owning to the versatility of LBL as an approach, and due to use of polymer-based building blocks. Therefore, different chemical (e.g., hydrophilicity/hydrophilicity, 
charge interactions) or physical modifications (e.g., barrier thickness, mesh size) can be easily incorporated, to tailor networks with specific characteristics.

By utilizing PEG based diblock copolymers, these synthetic mucin scaffolds displayed excellent surface wettability (Figure 8f), with contact angles comparable to natural mucin coats. Additionally, by utilizing its porous topography, the scaffolds improved the bacterial adhesion. By incorporating anti-bacterial drug loading (e.g., curcumin) within micellar core, they can demonstrate bacterial inhibition. Since, the framework for scaffold development involve the use of drug loaded nanocarriers, the synthetic mucin networks can translate into a functional coating capable of localized drug delivery with added biomimetic interfacial characteristics (Figure 9) [84].
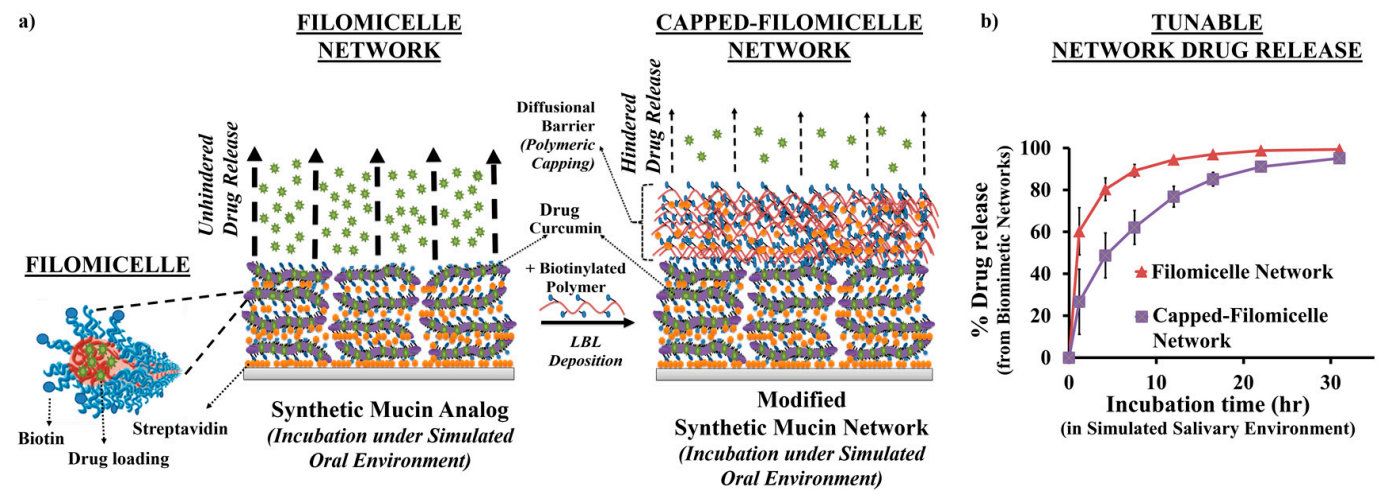

Figure 9. Potential synthetic mucin analogs as a tunable drug releasing network (a) Scheme showing use of filomicelle networks formed from crosslinking of biotinylated micelles with streptavidin, as a synthetic mucin analog. And, modification of those analog systems using polymeric capping barriers formed atop synthetic mucin. Capping barriers are formed from crosslinking of biotinylated polymer poly(acrylic acid) with streptavidin via LBL depositions; (b) Figure shows modification of drug release capacity from synthetic mucin systems for localized oral drug delivery applications. By developing polymeric capping barrier, the drug release from micelle-based network was greatly hindered, suggesting its capable potential to serve as tunable release systems for mucosal specific regenerative applications such as xerostomia and oral mucositis. Reprinted with permission from Reference [84]. Copyright $\odot ~ 2015$, Wiley-VCH Verlag GmbH \& Co. KGaA, Weinheim.

In a more recent study, Fiegel et al., (2013) [207] developed a model of tracheal mucus. To mimic the bulk chemical and interfacial properties as the natural counterpart, the model mucus were formulated from constituents derived from tracheal mucus (glycoproteins, proteins, lipids, ions, and water). The constituents were cross-linked into a viscoelastic gel via the use of a bifunctional crosslinking agent. By controlling the crosslinker amounts, the viscoelastic properties of the synthetic mucus can be tailored to mimic variations in native mucus. Likewise, a study by Lagarce et al., (2014) [208] used in vitro 2D and 3D models to study drug nanocarrier diffusion across mucin. In the 2D model, a mucin monolayer was formed, while the 3D model was developed through multiple sequential depositions, forming thick mucus barriers $(446 \mu \mathrm{m})$ over Transwell ${ }^{\circledR}$ membranes. The study used duodenum and jejunum mucus extracts from pig mucosal surface, in evaluating paclitaxel loaded lipid nanocapsule diffusion across mucus. Their work suggested 2D models can be potentially used for accessing transport behavior in air-water-mucus interface, while 3D model can find more relevance in studying mucin-particle diffusional transport behavior. For practical applications, the ability of those in vitro models to serve as an effective alternate for in vivo models needs to be accessed, through correlation of results from both the model systems.

Study by Burruano et al., (2002) [209,210], described use of guar gum, a polysaccharide based formulation approach as a synthetic alternate of cervical mucus. In their work, guar gum was crosslinked with borate ions to recreate the viscoelastic properties of mucus. The biomimetic tendency 
of those synthetic gels was studied by cross-comparing its rheological properties such as spinnbarkeit and viscocity, and suggesting its close relevance to naturally occurring cervical mucus.

Wang et al., (2014) [211], in their work used reversible addition-fragmentation chain transfer (RAFT) polymerization technique for synthesizing fluorophore tagged glycopolymers. In an attempt to mimic the randomly distributed glycomonomers as seen in natural mucin glycoproteins, the study used statistical tri-component copolymers. The glycopolymers were formed from the constituents glycomonomer, $\mathrm{N}$-(2-hydroxyethyl) acrylamide (HEAA) as spacer, and $\mathrm{N}$-(2-aminoethyl)methacrylamide (AEMA) as targets for fluorophore functionalization. Those custom-synthesized fluorescent glycopolymers contained $\alpha$-galactose or $\beta$-galactose as pendant sugar moieties, and displayed lectin-mediated binding tendency $[212,213]$ in human respiratory pathogenic bacteria (e.g., Pseudomonas aeruginosa and Staphylococcus aureus), thereby mimicking the bacterial adherence tendency of natural mucin.

\subsection{Significance of Mucus Mimetic Systems}

The bulk functional properties of natural mucin networks (e.g., mucoadhesion, bacterial capture, barrier properties) emanate from their complex interplay of molecular interactions and structural and chemical properties. By developing a modular structural mimic, which is capable of easily tuning its network property (e.g., morphology, mesh size, thickness, chemistry), the bulk behavior in natural mucin can be easily decoupled, allowing one to identify its relative significance. In addition, under in vitro settings, the surface deposition of natural mucin may not provide sufficient level of control, as it is extremely difficult to recreate the varied structures mucin can adopt throughout the body (e.g., cervical mucus, salivary pellicles, etc.). Alternatively, synthetic analog offer a relatively simple way to incorporate changes in the network morphology and its chemistry. For instance, by adjusting the polymer chemistry (e.g., molecular weights, pendant chain chemistries) s, the networks bulk chemistry can be tailored. For example, the glycan chains are the key contributor for mucin's lubricous nature. The extended conformation of mucin is due to the dense molecular arrangement of glycan chains, which orients the polypeptide core from globular to a more extended-conformation, forming rod-like structures [214]. These oligosaccharide residues can be incorporated onto polymeric chains, to yield a lubricous hydrophilic barrier. Studies by Levine et al., (1978) [215] and Stinson et al., (1982) [216], have suggested that sialic acid present in oligosaccharide chains can aid in bacterial entrapment (e.g., Streptococcus sanguis, Streptococcus mutans). These oligosaccharide residues can be incorporated for bacterial agglutination.

Conceptually, utilizing synthetic mucin analogs as a functional model, is still in its early exploratory stage. Some of the key considerations in developing synthetic mucin analogs are (1) requires a facile approach (e.g., polymeric layer-by-layer deposition (self-assembling)/polymeric gelation (bulk cross-linking)/ controlled surface growth) in forming analogs; (2) the approach should be highly modular and versatile that is capable of developing networks with tunable structural (e.g., morphology, barrier thickness, network mesh size) and chemical property (e.g., charge, hydrophobicity); (3) ability to easily elicit physicochemical modifications in component building blocks (e.g., polymeric systems); (4) the approach should be capable of recreating the formation mechanism of natural mucin networks and (5) synthetic networks should be capable of structurally and functionally mimicking bulk properties of natural networks (e.g., mucoadherence, lubricity, microbial capture/inhibition).

By developing an effective synthetic mucin system, the analogs can play a vital role, in evaluating studies that were highly reliant on natural mucins barrier and its adhesive properties. For instance, the development of drug deliverable patches (e.g., mucoadhesive buccal patches) or for studying the transport properties across mucus barrier in evaluating trans-mucosal drug delivery. The development and use of effective synthetic model lessens our overdependence on in vivo and ex vivo testing, thereby reduces the associated costs and the need for animal sacrifices. Therefore, the analog systems can serve as a prescreening process prior to conducting on a more rigorous animal model [201,217]. 
Alternatively, these synthetic analog systems can be also explored for potential prospect for biological applications. The biomimetic tendency, and need for porous biocompatible scaffoldings forms a key prerequisite in development of functional materials (e.g., use of porous synthetic extracellular matrix as tissue scaffolds), or developing functional coats in rendering epithelial protection and localized payload delivery from drug loaded networks [218]. For example, in the recently published work, Authimoolam et al. [84] with minor polymeric barrier modifications to the synthetic mucin analog, the ability to utilize these biomimic models as a tunable drug releasing structure was illustrated (Figures 8 and 9).

\section{Conclusions}

Mucin networks are found as a mucosal lining along different epithelial regions within human body. These networks are often considered as a transport barrier that needs to be overcome in many drug delivery applications. However, they play a critical functional role in impacting diverse array of physiological function. With lack of mucin barrier functionality, its effects can be readily perceived (e.g., nasal/oral/eye dryness, stomach ulcers).

Mucin network's functional behavior, as any complex polymeric gel system, is directly linked to its structural and chemical properties, and this dependency can be altered by changes in its local environmental conditions (e.g., salt, $\mathrm{pH}$ conditions). Due to such complexity, there is an unmet need for an effective mucin model that can easily recreate the complex structures under in vitro settings. By developing polymer based biomimetic synthetic analogs, and utilizing the tunable physiochemical nature of polymeric building blocks, facile control of network properties can be achieved. Such tunable networks apart from serving as a preclinical mucin model, by utilizing its biomimetic tendency, can be looked upon for its potential in various bioapplications such as developing biomaterial coatings, or in designing drug delivery systems (e.g., drug releasing scaffolds) for tissue engineering applications.

Acknowledgments: This work was funded by National Institutes of Health (Grant R03 DE019496).

Author Contributions: Sundar P. Authimoolam reviewed the literature and wrote the article, Thomas D. Dziubla edited, discussed, and guided in forming the overall structure of this review article.

Conflicts of Interest: The authors declare no conflict of interest.

\section{References}

1. Rogers, D.F. Airway goblet cells: Responsive and adaptable front-line defenders. Eur. Respir. J. 1994, 7 , 1690-1706. [CrossRef] [PubMed]

2. Murray, P.A.; Levine, M.J.; Tabak, L.A.; Reddy, M.S. Specificity of salivary-bacterial interactions. 2. Evidence for a lectin on streptococcus sanguis with specificity for a NeuAc- $\alpha-2,3 \mathrm{Ga} 1-\beta-1,3 \mathrm{Ga}$ 1nac sequence. Biochem. Biophys. Res. Commun. 1982, 106, 390-396. [CrossRef]

3. Kim, Y.; Dalhaimer, P.; Christian, D.A.; Discher, D.E. Polymeric worm micelles as nano-carriers for drug delivery. Nanotechnology 2005, 16, S484-S491. [CrossRef] [PubMed]

4. Bradway, S.D.; Bergey, E.J.; Jones, P.C.; Levine, M.J. Oral mucosal pellicle. Adsorption and transpeptidation of salivary components to buccal epithelial cells. Biochem. J. 1989, 261, 887-896. [CrossRef] [PubMed]

5. Kaditi, E.; Mountrichas, G.; Pispas, S.; Demetzos, C. Block copolymers for drug delivery nano systems (DDnSs). Curr. Med. Chem. 2012, 19, 5088-5100. [CrossRef] [PubMed]

6. Praud, A.; Bootzeek, O.; Blache, Y. Synthesis of polymerizable vinyltriazoles: Development of an optimized one-pot strategy starting from 4-bromobutyne. Green Chem. 2013, 15, 1138-1141. [CrossRef]

7. Bae, S.J.; Choi, H.; Choi, J.S. Synthesis of polymerizable amphiphiles with basic oligopeptides for gene delivery application. Polymer Korea 2013, 37, 94-99. [CrossRef]

8. Prakobphol, A.; Levine, M.J.; Tabak, L.A.; Reddy, M.S. Purification of a low-molecular-weight, mucin-type glycoprotein from human submandibular-sublingual saliva. Carbohydr. Res. 1982, 108, 111-122. [CrossRef]

9. Tabak, L.A. In defense of the oral cavity: The protective role of the salivary secretions. Pediatr. Dent. 2006, 28, 110-117. [PubMed] 
10. Hill, H.D., Jr.; Reynolds, J.A.; Hill, R.L. Purification, composition, molecular weight, and subunit structure of ovine submaxillary mucin. J. Biol. Chem. 1977, 252, 3791-3798. [PubMed]

11. Thornton, D.J.; Rousseau, K.; McGuckin, M.A. Structure and function of the polymeric mucins in airways mucus. Annu. Rev. Physiol. 2008, 70, 459-486. [CrossRef] [PubMed]

12. Sigurdsson, H.H.; Kirch, J.; Lehr, C.M. Mucus as a barrier to lipophilic drugs. Int. J. Pharm. 2013, 453, 56-64. [CrossRef] [PubMed]

13. Edsman, K.; Hagerstrom, H. Pharmaceutical applications of mucoadhesion for the non-oral routes. J. Pharm. Pharmacol. 2005, 57, 3-22. [CrossRef] [PubMed]

14. Bradway, S.D.; Bergey, E.J.; Scannapieco, F.A.; Ramasubbu, N.; Zawacki, S.; Levine, M.J. Formation of salivary-mucosal pellicle: The role of transglutaminase. Biochem. J. 1992, 284 Pt 2, 557-564. [CrossRef] [PubMed]

15. Authimoolam, S.P.; Vasilakes, A.L.; Shah, N.M.; Puleo, D.A.; Dziubla, T.D. Synthetic oral mucin mimic from polymer micelle networks. Biomacromolecules 2014, 15, 3099-3111. [CrossRef] [PubMed]

16. Gibbins, H.L.; Yakubov, G.E.; Proctor, G.B.; Wilson, S.; Carpenter, G.H. What interactions drive the salivary mucosal pellicle formation? Colloid Surf. B 2014, 120, 184-192. [CrossRef] [PubMed]

17. Houver, G.J.; Frank, R.M. Ultrastructural study of human dental plaque. Inf. Dent. 1971, 53, 4191-4200. [PubMed]

18. Lie, T. Scanning and transmission electron microscope study of pellicle morphogenesis. Scand. J. Dent. Res. 1977, 85, 217-231. [CrossRef] [PubMed]

19. Lendenmann, U.; Grogan, J.; Oppenheim, F.G. Saliva and dental pellicle-A review. Adv. Dent. Res. 2000, 14, 22-28. [CrossRef] [PubMed]

20. Hong, Z.N.; Chasan, B.; Bansil, R.; Turner, B.S.; Bhaskar, K.R.; Afdhal, N.H. Atomic force microscopy reveals aggregation of gastric mucin at low ph. Biomacromolecules 2005, 6, 3458-3466. [CrossRef] [PubMed]

21. Baek, J.H.; Krasieva, T.; Tang, S.; Ahn, Y.; Kim, C.S.; Vu, D.; Chen, Z.; Wilder-Smith, P. Optical approach to the salivary pellicle. J. Biomed. Opt. 2009, 14. [CrossRef] [PubMed]

22. Johansson, M.E.; Larsson, J.M.; Hansson, G.C. The two mucus layers of colon are organized by the muc2 mucin, whereas the outer layer is a legislator of host-microbial interactions. Proc. Natl. Acad. Sci. USA 2011, 108, 4659-4665. [CrossRef] [PubMed]

23. Cone, R.A. Barrier properties of mucus. Adv. Drug Deliver. Rev. 2009, 61, 75-85. [CrossRef] [PubMed]

24. Khanvilkar, K.; Donovan, M.D.; Flanagan, D.R. Drug transfer through mucus. Adv. Drug Deliv. Rev. 2001, 48, 173-193. [CrossRef]

25. Atuma, C.; Strugala, V.; Allen, A.; Holm, L. The adherent gastrointestinal mucus gel layer: Thickness and physical state in vivo. Am. J. Physiol. Gastrointest. Liver Physiol. 2001, 280, G922-G929. [PubMed]

26. Johansson, M.E.V.; Phillipson, M.; Petersson, J.; Velcich, A.; Holm, L.; Hansson, G.C. The inner of the two muc2 mucin-dependent mucus layers in colon is devoid of bacteria. Proc. Natl. Acad. Sci. USA 2008, 105, 15064-15069. [CrossRef] [PubMed]

27. Gustafsson, J.K.; Ermund, A.; Johansson, M.E.V.; Schutte, A.; Hansson, G.C.; Sjovall, H. An ex vivo method for studying mucus formation, properties, and thickness in human colonic biopsies and mouse small and large intestinal explants. Am. J. Physiol. Gastrointest. Liver Physiol. 2012, 302, G430-G438. [CrossRef] [PubMed]

28. Morgenroth, K.; Bolz, J. Morphological features of the interaction between mucus and surfactant on the bronchial-mucosa. Respiration 1985, 47, 225-231. [CrossRef] [PubMed]

29. Ha, E.V.; Rogers, D.F. Novel therapies to inhibit mucus synthesis and secretion in airway hypersecretory diseases. Pharmacology 2016, 97, 84-100. [CrossRef] [PubMed]

30. Cao, X.; Bansil, R.; Bhaskar, K.R.; Turner, B.S.; LaMont, J.T.; Niu, N.; Afdhal, N.H. pH-dependent conformational change of gastric mucin leads to sol-gel transition. Biophys. J. 1999, 76, 1250-1258. [CrossRef]

31. Brunelli, R.; Papi, M.; Arcovito, G.; Bompiani, A.; Castagnola, M.; Parasassi, T.; Sampaolese, B.; Vincenzoni, F.; de Spirito, M. Globular structure of human ovulatory cervical mucus. FASEB J. 2007, 21, 3872-3876. [CrossRef] [PubMed]

32. Menarguez, M.; Pastor, L.M.; Odeblad, E. Morphological characterization of different human cervical mucus types using light and scanning electron microscopy. Hum. Reprod. 2003, 18, 1782-1789. [CrossRef] [PubMed]

33. Kirkham, S.; Sheehan, J.K.; Knight, D.; Richardson, P.S.; Thornton, D.J. Heterogeneity of airways mucus: Variations in the amounts and glycoforms of the major oligomeric mucins muc5ac and muc5b. Biochem. J. 2002, 361, 537-546. [CrossRef] [PubMed] 
34. Lai, S.K.; Wang, Y.Y.; Hanes, J. Mucus-penetrating nanoparticles for drug and gene delivery to mucosal tissues. Adv. Drug Deliv. Rev. 2009, 61, 158-171. [CrossRef] [PubMed]

35. Round, A.N.; Berry, M.; McMaster, T.J.; Stoll, S.; Gowers, D.; Corfield, A.P.; Miles, M.J. Heterogeneity and persistence length in human ocular mucins. Biophys. J. 2002, 83, 1661-1670. [CrossRef]

36. Bansil, R.; Turner, B.S. Mucin structure, aggregation, physiological functions and biomedical applications. Curr. Opin. Colloid Interface Sci. 2006, 11, 164-170. [CrossRef]

37. Allen, A.; Leonard, A.J.; Sellers, L.A. The mucus barrier. Its role in gastroduodenal mucosal protection. J. Clin. Gastroenterol. 1988, 10, S93-S98. [CrossRef] [PubMed]

38. Ermund, A.; Schutte, A.; Johansson, M.E.; Gustafsson, J.K.; Hansson, G.C. Studies of mucus in mouse stomach, small intestine, and colon. I. Gastrointestinal mucus layers have different properties depending on location as well as over the peyer's patches. Am. J. Physiol. Gastrointest. Liver. Physiol. 2013, 305, G341-G347. [CrossRef] [PubMed]

39. Collins, L.M.; Dawes, C. The surface area of the adult human mouth and thickness of the salivary film covering the teeth and oral mucosa. J. Dent. Res. 1987, 66, 1300-1302. [CrossRef] [PubMed]

40. Olmsted, S.S.; Padgett, J.L.; Yudin, A.I.; Whaley, K.J.; Moench, T.R.; Cone, R.A. Diffusion of macromolecules and virus-like particles in human cervical mucus. Biophys. J. 2001, 81, 1930-1937. [CrossRef]

41. Allen, A.; Flemstrom, G.; Garner, A.; Kivilaakso, E. Gastroduodenal mucosal protection. Physiol. Rev. 1993, 73, 823-857. [PubMed]

42. Kirch, J.; Schneider, A.; Abou, B.; Hopf, A.; Schaefer, U.F.; Schneider, M.; Schall, C.; Wagner, C.; Lehr, C.M. Optical tweezers reveal relationship between microstructure and nanoparticle penetration of pulmonary mucus. Proc. Natl. Acad. Sci. USA 2012, 109, 18355-18360. [CrossRef] [PubMed]

43. Tinanoff, N.; Glick, P.L.; Weber, D.F. Ultrastructure of organic films on the enamel surface. Caries Res. 1976, 10, 19-32. [CrossRef] [PubMed]

44. De Vrese, M.; Marteau, P.R. Probiotics and prebiotics: Effects on diarrhea. J. Nutr. 2007, 137, 803S-811S. [PubMed]

45. Matsui, H.; Wagner, V.E.; Hill, D.B.; Schwab, U.E.; Rogers, T.D.; Button, B.; Taylor, R.M.; Superfine, R.; Rubinstein, M.; Iglewski, B.H.; et al. A physical linkage between cystic fibrosis airway surface dehydration and pseudomonas aeruginosa biofilms. Proc. Natl. Acad. Sci. USA 2006, 103, 18131-18136. [CrossRef] [PubMed]

46. Oliver, D. Microbes and you: Normal flora. Available online: http://www.scq.ubc.ca/microbes-andyou-normal-flora/ (accessed on 20 August 2006).

47. Chao, C.C.; Stuebben, A.M.; Butala, S.M. Characterization of ocular mucus extracts by crossed immunoelectrophoretic techniques. Investig. Ophthalmol. Vis. Sci. 1990, 31, 1127-1135.

48. Holly, F.J.; Lemp, M.A. Tear physiology and dry eyes. Surv. Ophthalmol. 1977, 22, 69-87. [CrossRef]

49. Mantelli, F.; Argueso, P. Functions of ocular surface mucins in health and disease. Curr. Opin. Allergy Clin. Immunol. 2008, 8, 477-483. [CrossRef] [PubMed]

50. Tan, J.; Keay, L.; Jalbert, I.; Naduvilath, T.J.; Sweeney, D.F.; Holden, B.A. Mucin balls with wear of conventional and silicone hydrogel contact lenses. Optom. Vis. Sci. 2003, 80, 291-297. [CrossRef] [PubMed]

51. Szczotka-Flynn, L.; Benetz, B.A.; Lass, J.; Albright, M.; Gillespie, B.; Kuo, J.; Fonn, D.; Sethi, A.; Rimm, A. The association between mucin balls and corneal infiltrative events during extended contact lens wear. Cornea 2011, 30, 535-542. [CrossRef] [PubMed]

52. Hopcraft, M.S.; Tan, C. Xerostomia: An update for clinicians. Aust. Dent. J. 2010, 55, 238-244. [CrossRef] [PubMed]

53. Sasportas, L.S.; Hosford, D.N.; Sodini, M.A.; Waters, D.J.; Zambricki, E.A.; Barral, J.K.; Graves, E.E.; Brinton, T.J.; Yock, P.G.; le, Q.T.; et al. Cost-effectiveness landscape analysis of treatments addressing xerostomia in patients receiving head and neck radiation therapy. Oral Surg. Oral Med. Oral Pathol. Oral Radiol. 2013, 116, E37-E51. [CrossRef] [PubMed]

54. Turner, M.D.; Ship, J.A. Dry mouth and its effects on the oral health of elderly people. J. Am. Dent. Assoc. 2007, 138, 15s-20s. [CrossRef] [PubMed]

55. Mese, H.; Matsuo, R. Salivary secretion, taste and hyposalivation. J. Oral Rehabil. 2007, 34, 711-723. [CrossRef] [PubMed]

56. Xu, T.; Levitz, S.M.; Diamond, R.D.; Oppenheim, F.G. Anticandidal activity of major human salivary histatins. Infect. Immun. 1991, 59, 2549-2554. [PubMed] 
57. Kavanagh, K.; Dowd, S. Histatins: Antimicrobial peptides with therapeutic potential. J. Pharm. Pharmacol. 2004, 56, 285-289. [CrossRef] [PubMed]

58. Torres, S.R.; Garzino-Demo, A.; Meiller, T.F.; Meeks, V.; Jabra-Rizk, M.A. Salivary histatin-5 and oral fungal colonisation in HIV+ individuals. Mycoses 2009, 52, 11-15. [CrossRef] [PubMed]

59. Muralidharan, R.; Bobek, L.A. Antifungal activity of human salivary mucin-derived peptide, muc7 12-mer, in a murine model of oral candidiasis. J. Pept. Res. 2005, 66, 82-89. [CrossRef]

60. Lin, A.L.; Johnson, D.A.; Patterson, T.F.; Wu, Y.; Lu, D.L.; Shi, Q.; Yeh, C.K. Salivary anticandidal activity and saliva composition in an HIV-infected cohort. Oral Microbiol. Immunol. 2001, 16, 270-278. [CrossRef] [PubMed]

61. Jainkittivong, A.; Lin, A.L.; Johnson, D.A.; Langlais, R.P.; Yeh, C.K. Salivary secretion, mucin concentrations and candida carriage in HIV-infected patients. Oral Dis. 2009, 15, 229-234. [CrossRef] [PubMed]

62. Khan, S.A.; Fidel, P.L., Jr.; Thunayyan, A.A.; Varlotta, S.; Meiller, T.F.; Jabra-Rizk, M.A. Impaired histatin-5 levels and salivary antimicrobial activity against in hiv infected individuals. J. AIDS Clin. Res. 2013, 4. [CrossRef] [PubMed]

63. Kim, W.D. Lung mucus: A clinician's view. Eur. Respir. J. 1997, 10, 1914-1917. [CrossRef] [PubMed]

64. Clamp, J.R.; Ene, D. The gastric-mucosal barrier. Method Find Exp. Clin. 1989, 11, 19-25.

65. Allen, A.; Flemstrom, G. Gastroduodenal mucus bicarbonate barrier: Protection against acid and pepsin. Am. J. Physiol. Cell Physiol. 2005, 288, C1-C19. [CrossRef] [PubMed]

66. Crampton, J.R. Gastroduodenal mucus and bicarbonate-The defensive zone. Q. J. Med. 1988, 67, $269-272$. [PubMed]

67. Juntunen, M.; Kirjavainen, P.V.; Ouwehand, A.C.; Salminen, S.J.; Isolauri, E. Adherence of probiotic bacteria to human intestinal mucus in healthy infants and during rotavirus infection. Clin. Diagn. Lab. Immunol. 2001, 8, 293-296. [CrossRef] [PubMed]

68. Chen, S.J.; Liu, X.W.; Liu, J.P.; Yang, X.Y.; Lu, F.G. Ulcerative colitis as a polymicrobial infection characterized by sustained broken mucus barrier. World J. Gastroenterol. 2014, 20, 9468-9475. [PubMed]

69. Vaughan, E.E.; Mollet, B. Probiotics in the new millennium. Die Nahr. 1999, 43, 148-153. [CrossRef]

70. Cremonini, F.; di Caro, S.; Nista, E.C.; Bartolozzi, F.; Capelli, G.; Gasbarrini, G.; Gasbarrini, A. Meta-analysis: The effect of probiotic administration on antibiotic-associated diarrhoea. Aliment. Pharmacol. Ther. 2002, 16, 1461-1467. [CrossRef] [PubMed]

71. Verna, E.C.; Lucak, S. Use of probiotics in gastrointestinal disorders: What to recommend? Ther. Adv. Gastroenterol. 2010, 3, 307-319. [CrossRef] [PubMed]

72. Allen, S.J.; Martinez, E.G.; Gregorio, G.V.; Dans, L.F. Probiotics for treating acute infectious diarrhoea. Sao Paulo Med. J. 2011, 129, 185. [CrossRef]

73. Ohland, C.L.; Macnaughton, W.K. Probiotic bacteria and intestinal epithelial barrier function. Am. J. Physiol. Gastrointest. Liver Physiol. 2010, 298, G807-G819. [CrossRef] [PubMed]

74. Lai, S.K.; Wang, Y.Y.; Hida, K.; Cone, R.; Hanes, J. Nanoparticles reveal that human cervicovaginal mucus is riddled with pores larger than viruses. Proc. Natl. Acad. Sci. USA 2010, 107, 598-603. [CrossRef] [PubMed]

75. Lieleg, O.; Lieleg, C.; Bloom, J.; Buck, C.B.; Ribbeck, K. Mucin biopolymers as broad-spectrum antiviral agents. Biomacromolecules 2012, 13, 1724-1732. [CrossRef] [PubMed]

76. Elstein, M. Cervical mucus: Its physiological role and clinical significance. Adv. Exp. Med. Biol. 1982, 144, 301-318. [PubMed]

77. Becher, N.; Adams Waldorf, K.; Hein, M.; Uldbjerg, N. The cervical mucus plug: Structured review of the literature. Acta Obstet. Gynecol. Scand. 2009, 88, 502-513. [CrossRef] [PubMed]

78. Shukair, S.A.; Allen, S.A.; Cianci, G.C.; Stieh, D.J.; Anderson, M.R.; Baig, S.M.; Gioia, C.J.; Spongberg, E.J.; Kauffman, S.M.; McRaven, M.D.; et al. Human cervicovaginal mucus contains an activity that hinders HIV-1 movement. Mucosal Immunol. 2013, 6, 427-434. [CrossRef] [PubMed]

79. Boukari, H.; Brichacek, B.; Stratton, P.; Mahoney, S.F.; Lifson, J.D.; Margolis, L.; Nossal, R. Movements of HIV-virions in human cervical mucus. Biomacromolecules 2009, 10, 2482-2488. [CrossRef] [PubMed]

80. Chretien, F.C. Ultrastructure and variations of human cervical mucus during pregnancy and the menopause. Acta Obstet. Gynecol. Scand. 1978, 57, 337-348. [CrossRef] [PubMed]

81. Moore, W.E.; Moore, L.V. The bacteria of periodontal diseases. Periodontology 2000 1994, 5, 66-77. [CrossRef] [PubMed] 
82. Paster, B.J.; Boches, S.K.; Galvin, J.L.; Ericson, R.E.; Lau, C.N.; Levanos, V.A.; Sahasrabudhe, A.; Dewhirst, F.E. Bacterial diversity in human subgingival plaque. J. Bacteriol. 2001, 183, 3770-3783. [CrossRef] [PubMed]

83. Aas, J.A.; Paster, B.J.; Stokes, L.N.; Olsen, I.; Dewhirst, F.E. Defining the normal bacterial flora of the oral cavity. J. Clin. Microbiol. 2005, 43, 5721-5732. [CrossRef] [PubMed]

84. Authimoolam, S.P.; Lakes, A.L.; Puleo, D.A.; Dziubla, T.D. Layer-by-layers of polymeric micelles as a biomimetic drug-releasing network. Macromol. Biosci. 2015. [CrossRef] [PubMed]

85. Nieuw Amerongen, A.V.; Oderkerk, C.H.; Driessen, A.A. Role of mucins from human whole saliva in the protection of tooth enamel against demineralization in vitro. Caries Res. 1987, 21, 297-309. [CrossRef] [PubMed]

86. Bonilha, H.S.; White, L.; Kuckhahn, K.; Gerlach, T.T.; Deliyski, D.D. Vocal fold mucus aggregation in persons with voice disorders. J. Commun. Disord. 2012, 45, 304-311. [CrossRef] [PubMed]

87. Ramos, F.L.; Krahnke, J.S.; Kim, V. Clinical issues of mucus accumulation in copd. Int. J. Chronic Obstr. Pulm. Dis. 2014, 9, 139-150.

88. Izuhara, K.; Ohta, S.; Shiraishi, H.; Suzuki, S.; Taniguchi, K.; Toda, S.; Tanabe, T.; Yasuo, M.; Kubo, K.; Hoshino, T.; et al. The mechanism of mucus production in bronchial asthma. Curr. Med. Chem. 2009, 16, 2867-2875. [CrossRef] [PubMed]

89. Matsui, H.; Verghese, M.W.; Kesimer, M.; Schwab, U.E.; Randell, S.H.; Sheehan, J.K.; Grubb, B.R.; Boucher, R.C. Reduced three-dimensional motility in dehydrated airway mucus prevents neutrophil capture and killing bacteria on airway epithelial surfaces. J. Immunol. 2005, 175, 1090-1099. [CrossRef] [PubMed]

90. Nesbitt, W.E.; Doyle, R.J.; Taylor, K.G. Hydrophobic interactions and the adherence of streptococcus sanguis to hydroxylapatite. Infect. Immun. 1982, 38, 637-644. [PubMed]

91. Tabak, L.A.; Levine, M.J.; Mandel, I.D.; Ellison, S.A. Role of salivary mucins in the protection of the oral cavity. J. Oral Pathol. 1982, 11, 1-17. [CrossRef] [PubMed]

92. McBride, B.C.; Gisslow, M.T. Role of sialic acid in saliva-induced aggregation of streptococcus sanguis. Infect. Immun. 1977, 18, 35-40. [PubMed]

93. Gibbons, R.J. Bacterial adhesion to oral tissues: A model for infectious diseases. J. Dent. Res. 1989, 68, 750-760. [CrossRef] [PubMed]

94. Loomis, R.E.; Prakobphol, A.; Levine, M.J.; Reddy, M.S.; Jones, P.C. Biochemical and biophysical comparison of two mucins from human submandibular-sublingual saliva. Arch. Biochem. Biophys. 1987, 258, 452-464. [CrossRef]

95. Levine, M.J.; Reddy, M.S.; Tabak, L.A.; Loomis, R.E.; Bergey, E.J.; Jones, P.C.; Cohen, R.E.; Stinson, M.W.; Al-Hashimi, I. Structural aspects of salivary glycoproteins. J. Dent. Res. 1987, 66, 436-441. [CrossRef] [PubMed]

96. Jachak, A.; Lai, S.K.; Hida, K.; Suk, J.S.; Markovic, N.; Biswal, S.; Breysse, P.N.; Hanes, J. Transport of metal oxide nanoparticles and single-walled carbon nanotubes in human mucus. Nanotoxicology 2012, 6, 614-622. [CrossRef] [PubMed]

97. Coaker, H. Development and in vitro evaluation of slippery nanoparticles for enhanced diffusion through native mucus. Nanomedicine UK 2014, 9, 382-383.

98. Crater, J.S.; Carrier, R.L. Barrier properties of gastrointestinal mucus to nanoparticle transport. Macromol. Biosci. 2010, 10, 1473-1483. [CrossRef] [PubMed]

99. Li, L.D.; Crouzier, T.; Sarkar, A.; Dunphy, L.; Han, J.; Ribbeck, K. Spatial configuration and composition of charge modulates transport into a mucin hydrogel barrier. Biophys. J. 2013, 105, 1357-1365. [CrossRef] [PubMed]

100. Wang, Y.Y.; Lai, S.K.; Suk, J.S.; Pace, A.; Cone, R.; Hanes, J. Addressing the PEG mucoadhesivity paradox to engineer nanoparticles that "slip" through the human mucus barrier. Angew. Chem. Int. Ed. Engl. 2008, 47, 9726-9729. [CrossRef] [PubMed]

101. Saltzman, W.M.; Radomsky, M.L.; Whaley, K.J.; Cone, R.A. Antibody diffusion in human cervical-mucus. Biophys. J. 1994, 66, 508-515. [CrossRef]

102. Chen, A.; McKinley, S.A.; Wang, S.; Shi, F.; Mucha, P.J.; Forest, M.G.; Lai, S.K. Transient antibody-mucin interactions produce a dynamic molecular shield against viral invasion. Biophys. J. 2014, 106, 2028-2036. [CrossRef] [PubMed] 
103. Wang, Y.Y.; Kannan, A.; Nunn, K.L.; Murphy, M.A.; Subramani, D.B.; Moench, T.; Cone, R.; Lai, S.K. IgG in cervicovaginal mucus traps HSV and prevents vaginal Herpes infections. Mucosal Immunol. 2014, 7 , 1036-1044. [CrossRef] [PubMed]

104. Fahrbach, K.M.; Malykhina, O.; Stieh, D.J.; Hope, T.J. Differential binding of IgG and IgA to mucus of the female reproductive tract. PLOS ONE 2013, 8, e76176. [CrossRef] [PubMed]

105. Cu, Y.; Saltzman, W.M. Drug delivery: Stealth particles give mucus the slip. Nat. Mater. 2009, 8, 11-13. [CrossRef] [PubMed]

106. Lieleg, O.; Ribbeck, K. Biological hydrogels as selective diffusion barriers. Trends Cell Biol. 2011, $21,543-551$. [CrossRef] [PubMed]

107. Ensign, L.M.; Tang, B.C.; Wang, Y.Y.; Tse, T.A.; Hoen, T.; Cone, R.; Hanes, J. Mucus-penetrating nanoparticles for vaginal drug delivery protect against herpes simplex virus. Sci. Transl. Med. 2012, 4. [CrossRef] [PubMed]

108. Thanou, M.; Verhoef, J.C.; Junginger, H.E. Oral drug absorption enhancement by chitosan and its derivatives. Adv. Drug Deliv. Rev. 2001, 52, 117-126. [CrossRef]

109. Karavas, E.; Georgarakis, E.; Bikiaris, D. Application of PVP/HPMC miscible blends with enhanced mucoadhesive properties for adjusting drug release in predictable pulsatile chronotherapeutics. Eur. J. Pharm. Biopharm. 2006, 64, 115-126. [CrossRef] [PubMed]

110. Ramineni, S.K.; Cunningham, L.L., Jr.; Dziubla, T.D.; Puleo, D.A. Competing properties of mucoadhesive films designed for localized delivery of imiquimod. Biomater. Sci. 2013, 1, 753-762. [CrossRef] [PubMed]

111. Ponchel, G.; Montisci, M.J.; Dembri, A.; Durrer, C.; Duchene, D. Mucoadhesion of colloidal particulate systems in the gastro-intestinal tract. Eur. J. Pharm. Biopharm. 1997, 44, 25-31. [CrossRef]

112. Larhed, A.W.; Artursson, P.; Grasjo, J.; Bjork, E. Diffusion of drugs in native and purified gastrointestinal mucus. J. Pharm. Sci. 1997, 86, 660-665. [CrossRef] [PubMed]

113. Larhed, A.W.; Artursson, P.; Bjork, E. The influence of intestinal mucus components on the diffusion of drugs. Pharm. Res 1998, 15, 66-71. [CrossRef] [PubMed]

114. Patil, S.B.; Sawant, K.K. Mucoadhesive microspheres: A promising tool in drug delivery. Curr. Drug Deliv. 2008, 5, 312-318. [CrossRef] [PubMed]

115. Araujo, F.; Shrestha, N.; Shahbazi, M.A.; Fonte, P.; Makila, E.M.; Salonen, J.J.; Hirvonen, J.T.; Granja, P.L.; Santos, H.A.; Sarmento, B. The impact of nanoparticles on the mucosal translocation and transport of GLP-1 across the intestinal epithelium. Biomaterials 2014, 35, 9199-9207. [CrossRef] [PubMed]

116. Ludwig, A. The use of mucoadhesive polymers in ocular drug delivery. Adv. Drug Deliv. Rev. 2005, 57, 1595-1639. [CrossRef] [PubMed]

117. Zhou, W.; Wang, Y.; Jian, J.; Song, S. Self-aggregated nanoparticles based on amphiphilic poly(lactic acid)-grafted-chitosan copolymer for ocular delivery of amphotericin B. Int. J. Nanomed. 2013, 8, 3715-3728.

118. Khutoryanskaya, O.V.; Morrison, P.W.; Seilkhanov, S.K.; Mussin, M.N.; Ozhmukhametova, E.K.; Rakhypbekov, T.K.; Khutoryanskiy, V.V. Hydrogen-bonded complexes and blends of poly(acrylic acid) and methylcellulose: Nanoparticles and mucoadhesive films for ocular delivery of riboflavin. Macromol. Biosci. 2014, 14, 225-234. [CrossRef] [PubMed]

119. Ceulemans, J.; Vermeire, A.; Adriaens, E.; Remon, J.P.; Ludwig, A. Evaluation of a mucoadhesive tablet for ocular use. J. Control. Release 2001, 77, 333-344. [CrossRef]

120. Salamat-Miller, N.; Chittchang, M.; Johnston, T.P. The use of mucoadhesive polymers in buccal drug delivery. Adv. Drug Deliv. Rev. 2005, 57, 1666-1691. [CrossRef] [PubMed]

121. Laffleur, F. Mucoadhesive polymers for buccal drug delivery. Drug Dev. Ind. Pharm. 2014, 40, 591-598. [CrossRef] [PubMed]

122. Xu, J.K.; Strandman, S.; Zhu, J.X.X.; Barralet, J.; Cerruti, M. Genipin-crosslinked catechol-chitosan mucoadhesive hydrogels for buccal drug delivery. Biomaterials 2015, 37, 395-404. [CrossRef] [PubMed]

123. Gavin, A.; Pham, J.T.H.; Wang, D.W.; Brownlow, B.; Elbayoumi, T.A. Layered nanoemulsions as mucoadhesive buccal systems for controlled delivery of oral cancer therapeutics. Int. J. Nanomed. 2015, 10, 1569-1584.

124. Sharma, N.; Kulkarni, G.T.; Sharma, A.; Bhatnagar, A.; Kumar, N. Natural mucoadhesive microspheres of Abelmoschus esculentus polysaccharide as a new carrier for nasal drug delivery. J. Microencapsul. 2013, 30, 589-598. [CrossRef] [PubMed]

125. Jiang, L.; Gao, L.; Wang, X.; Tang, L.; Ma, J. The application of mucoadhesive polymers in nasal drug delivery. Drug Dev. Ind. Pharm. 2010, 36, 323-336. [CrossRef] [PubMed] 
126. Hansen, K.; Kim, G.; Desai, K.G.; Patel, H.; Olsen, K.F.; Curtis-Fisk, J.; Tocce, E.; Jordan, S.; Schwendeman, S.P. Feasibility investigation of cellulose polymers for mucoadhesive nasal drug delivery applications. Mol. Pharm. 2015, 12, 2732-2741. [CrossRef] [PubMed]

127. Devkar, T.B.; Tekade, A.R.; Khandelwal, K.R. Surface engineered nanostructured lipid carriers for efficient nose to brain delivery of ondansetron $\mathrm{HCl}$ using delonix regia gum as a natural mucoadhesive polymer. Colloids Surf. B Biointerfaces 2014, 122, 143-150. [CrossRef] [PubMed]

128. Alpar, H.O.; Somavarapu, S.; Atuah, K.N.; Bramwell, V.W. Biodegradable mucoadhesive particulates for nasal and pulmonary antigen and DNA delivery. Adv. Drug Deliv. Rev. 2005, 57, 411-430. [CrossRef] [PubMed]

129. Alipour, S.; Montaseri, H.; Tafaghodi, M. Preparation and characterization of biodegradable paclitaxel loaded alginate microparticles for pulmonary delivery. Colloids Surf. B Biointerfaces 2010, 81, 521-529. [CrossRef] [PubMed]

130. Sakagami, M.; Sakon, K.; Kinoshita, W.; Makino, Y. Enhanced pulmonary absorption following aerosol administration of mucoadhesive powder microspheres. J. Control. Release 2001, 77, 117-129. [CrossRef]

131. Liu, X.B.; Ye, J.X.; Quan, L.H.; Liu, C.Y.; Deng, X.L.; Yang, M.; Liao, Y.H. Pulmonary delivery of scutellarin solution and mucoadhesive particles in rats. Eur. J. Pharm. Biopharm. 2008, 70, 845-852. [CrossRef] [PubMed]

132. De Araujo Pereira, R.R.; Bruschi, M.L. Vaginal mucoadhesive drug delivery systems. Drug Dev. Ind. Pharm. 2012, 38, 643-652. [CrossRef] [PubMed]

133. Valenta, C. The use of mucoadhesive polymers in vaginal delivery. Adv. Drug Deliv. Rev. 2005, 57, $1692-1712$. [CrossRef] [PubMed]

134. Acarturk, F. Mucoadhesive vaginal drug delivery systems. Recent Pat. Drug Deliv. Formul. 2009, 3, $193-205$. [CrossRef] [PubMed]

135. Caramella, C.M.; Rossi, S.; Ferrari, F.; Bonferoni, M.C.; Sandri, G. Mucoadhesive and thermogelling systems for vaginal drug delivery. Adv. Drug Deliv. Rev. 2015, 92, 39-52. [CrossRef] [PubMed]

136. Furst, T.; Piette, M.; Lechanteur, A.; Evrard, B.; Piel, G. Mucoadhesive cellulosic derivative sponges as drug delivery system for vaginal application. Eur. J. Pharm. Biopharm. 2015, 95, 128-135. [CrossRef] [PubMed]

137. Yuan, Y.; Cui, Y.; Zhang, L.; Zhu, H.P.; Guo, Y.S.; Zhong, B.; Hu, X.; Zhang, L.; Wang, X.H.; Chen, L. Thermosensitive and mucoadhesive in situ gel based on poloxamer as new carrier for rectal administration of nimesulide. Int. J. Pharm. 2012, 430, 114-119. [CrossRef] [PubMed]

138. Fawaz, F.; Koffi, A.; Guyot, M.; Millet, P. Comparative in vitro-in vivo study of two quinine rectal gel formulations. Int. J. Pharm. 2004, 280, 151-162. [CrossRef] [PubMed]

139. El-Leithy, E.S.; Shaker, D.S.; Ghorab, M.K.; Abdel-Rashid, R.S. Evaluation of mucoadhesive hydrogels loaded with diclofenac sodium-chitosan microspheres for rectal administration. AAPS PharmSciTech 2010, 11, 1695-1702. [CrossRef] [PubMed]

140. Ofokansi, K.C.; Adikwu, M.U.; Okore, V.C. Preparation and evaluation of mucin-gelatin mucoadhesive microspheres for rectal delivery of ceftriaxone sodium. Drug Dev. Ind. Pharm. 2007, 33, 691-700. [CrossRef] [PubMed]

141. Maurya, S.K.; Pathak, K.; Bali, V. Therapeutic potential of mucoadhesive drug delivery systems-An updated patent review. Recent Pat. Drug Deliv. Formul. 2010, 4, 256-265. [CrossRef] [PubMed]

142. Thasneem, Y.M.; Rekha, M.R.; Sajeesh, S.; Sharma, C.P. Biomimetic mucin modified plga nanoparticles for enhanced blood compatibility. J. Colloid Interface Sci. 2013, 409, 237-244. [CrossRef] [PubMed]

143. Janairo, R.R.R.; Zhu, Y.Q.; Chen, T.; Li, S. Mucin covalently bonded to microfibers improves the patency of vascular grafts. Tissue Eng. A 2014, 20, 285-293. [CrossRef] [PubMed]

144. Sandberg, T.; Karlsson Ott, M.; Carlsson, J.; Feiler, A.; Caldwell, K.D. Potential use of mucins as biomaterial coatings. Ii. Mucin coatings affect the conformation and neutrophil-activating properties of adsorbed host proteins-Toward a mucosal mimic. J. Biomed. Mater. Res. A 2009, 91, 773-785. [CrossRef] [PubMed]

145. Shi, L.; Ardehali, R.; Caldwell, K.D.; Valint, P. Mucin coating on polymeric material surfaces to suppress bacterial adhesion. Colloid Surf. B 2000, 17, 229-239. [CrossRef]

146. Crouzier, T.; Jang, H.; Ahn, J.; Stocker, R.; Ribbeck, K. Cell patterning with mucin biopolymers. Biomacromolecules 2013, 14, 3010-3016. [CrossRef] [PubMed]

147. Johnson, K.; Fath, K.; Henricus, M.; Banerjee, I. Self-assembly and growth of smart cell-adhesive mucin-bound microtubes. Soft Matter 2009, 7, 21-36. [CrossRef] 
148. Chen, X.; Lee, G.S.; Zettl, A.; Bertozzi, C.R. Biomimetic engineering of carbon nanotubes by using cell surface mucin mimics. Angew. Chem. Int. Ed. Engl. 2004, 43, 6111-6116. [CrossRef] [PubMed]

149. Drug, E.; Landesman-Milo, D.; Belgorodsky, B.; Ermakov, N.; Frenkel-Pinter, M.; Fadeev, L.; Peer, D.; Gozin, M. Enhanced bioavailability of polyaromatic hydrocarbons in the form of mucin complexes. Chem. Res. Toxicol. 2011, 24, 314-320. [CrossRef] [PubMed]

150. Belgorodsky, B.; Drug, E.; Fadeev, L.; Hendler, N.; Mentovich, E.; Gozin, M. Mucin complexes of nanomaterials: First biochemical encounter. Small 2010, 6, 262-269. [CrossRef] [PubMed]

151. Lasky, L.A.; Singer, M.S.; Dowbenko, D.; Imai, Y.; Henzel, W.J.; Grimley, C.; Fennie, C.; Gillett, N.; Watson, S.R.; Rosen, S.D. An endothelial ligand for l-selectin is a novel mucin-like molecule. Cell 1992, 69, 927-938. [CrossRef]

152. Wahrenbrock, M.; Borsig, L.; le, D.; Varki, N.; Varki, A. Selectin-mucin interactions as a probable molecular explanation for the association of trousseau syndrome with mucinous adenocarcinomas. J. Clin. Investig. 2003, 112, 853-862. [CrossRef] [PubMed]

153. Aigner, S.; Sthoeger, Z.M.; Fogel, M.; Weber, E.; Zarn, J.; Ruppert, M.; Zeller, Y.; Vestweber, D.; Stahel, R.; Sammar, M.; et al. CD24, a mucin-type glycoprotein, is a ligand for P-selectin on human tumor cells. Blood 1997, 89, 3385-3395. [PubMed]

154. Chen, S.H.; Dallas, M.R.; Balzer, E.M.; Konstantopoulos, K. Mucin 16 is a functional selectin ligand on pancreatic cancer cells. FASEB J. 2012, 26, 1349-1359. [CrossRef] [PubMed]

155. Carson, D.D.; Julian, J.; Lessey, B.A.; Prakobphol, A.; Fisher, S.J. Muc1 is a scaffold for selectin ligands in the human uterus. Front. Biosci. 2006, 11, 2903-2908. [CrossRef] [PubMed]

156. Crouzier, T.; Beckwitt, C.H.; Ribbeck, K. Mucin multilayers assembled through sugar-lectin interactions. Biomacromolecules 2012, 13, 3401-3408. [CrossRef] [PubMed]

157. Polak, R.; Crouzier, T.; Lim, R.M.; Ribbeck, K.; Beppu, M.M.; Pitombo, R.N.M.; Cohen, R.E.; Rubner, M.F. Sugar-mediated disassembly of mucin/lectin multi layers and their use as $\mathrm{pH}$-tolerant, on-demand sacrificial layers. Biomacromolecules 2014, 15, 3093-3098. [CrossRef] [PubMed]

158. Perez-Vilar, J.; Hill, R.L. The structure and assembly of secreted mucins. J. Biol. Chem. 1999, 274, 31751-31754. [CrossRef] [PubMed]

159. Jain, S.K.; Jangdey, M.S. Lectin conjugated gastroretentive multiparticulate delivery system of clarithromycin for the effective treatment of helicobacter pylori. Mol. Pharm. 2009, 6, 295-304. [CrossRef] [PubMed]

160. Adebisi, A.O.; Conway, B.R. Lectin-conjugated microspheres for eradication of helicobacter pylori infection and interaction with mucus. Int. J. Pharm. 2014, 470, 28-40. [CrossRef] [PubMed]

161. Wang, B.; Liu, Z.Y.; Xu, Y.L.; Li, Y.H.; An, T.Z.; Su, Z.H.; Peng, B.; Lin, Y.; Wang, Q. Construction of glycoprotein multilayers using the layer-by-layer assembly technique. J. Mater. Chem. 2012, 22, 17954-17960. [CrossRef]

162. Svensson, O.; Lindh, L.; Cardenas, M.; Arnebrant, T. Layer-by-layer assembly of mucin and chitosan-Influence of surface properties, concentration and type of mucin. J. Colloid Interface Sci. 2006, 299, 608-616. [CrossRef] [PubMed]

163. Ivanov, A.E.; Solodukhina, N.M.; Nilsson, L.; Nikitin, M.P.; Nikitin, P.I.; Zubov, V.P.; Vikhrov, A.A. Binding of mucin to water-soluble and surface-grafted boronate-containing polymers. Polym. Sci. Ser. A 2012, 54, 1-10. [CrossRef]

164. Ding, Z.B.; Guan, Y.; Zhang, Y.; Zhu, X.X. Layer-by-layer multilayer films linked with reversible boronate ester bonds with glucose-sensitivity under physiological conditions. Soft Matter 2009, 5, 2302-2309. [CrossRef]

165. Vissink, A.; Schaub, R.M.; van Rijn, L.J.; Gravenmade, E.J.; Panders, A.K.; Vermey, A. The efficacy of mucin-containing artificial saliva in alleviating symptoms of xerostomia. Gerodontology 1987, 6, 95-101. [CrossRef] [PubMed]

166. Blixt-Johansen, G.; Ek, A.C.; Ganowiak, W.; Granerus, A.K.; von Schenck, H.; Unosson, M.; Wiesel, K. Improvement of oral mucosa with mucin containing artificial saliva in geriatric patients. Arch. Gerontol. Geriatr. 1992, 14, 193-201. [CrossRef]

167. S-Gravenmade, E.J.; Roukema, P.A.; Panders, A.K. The effect of mucin-containing artificial saliva on severe xerostomia. Int. J. Oral Surg. 1974, 3, 435-439. [CrossRef]

168. Duxbury, A.J.; Thakker, N.S.; Wastell, D.G. A double-blind cross-over trial of a mucin-containing artificial saliva. Br. Dent. J. 1989, 166, 115-120. [CrossRef] [PubMed] 
169. Vissink, A.; Sgravenmade, E.J.; Panders, A.K.; Vermey, A.; Petersen, J.K.; Visch, L.L.; Schaub, R.M.H. A clinical comparison between commercially available mucin-containing and cmc-containing saliva substitutes. Int. J. Oral Surg. 1983, 12, 232-238. [CrossRef]

170. Vissink, A.; Waterman, H.A.; Sgravenmade, E.J.; Panders, A.K.; Vermey, A. Rheological properties of saliva substitutes containing mucin, carboxymethylcellulose or polyethylenoxide. J. Oral Pathol. Med. 1984, 13, 22-28. [CrossRef]

171. Davies, A.N.; Daniels, C.; Pugh, R.; Sharma, K. A comparison of artificial saliva and pilocarpine in the management of xerostomia in patients with advanced cancer. Palliat. Med. 1998, 12, 105-111. [CrossRef] [PubMed]

172. Sweeney, M.P.; Bagg, J.; Baxter, W.P.; Aitchison, T.C. Clinical trial of a mucin-containing oral spray for treatment of xerostomia in hospice patients. Palliat. Med. 1997, 11, 225-232. [CrossRef] [PubMed]

173. Duffy, C.V.; David, L.; Crouzier, T. Covalently-crosslinked mucin biopolymer hydrogels for sustained drug delivery. Acta Biomater. 2015, 20, 51-59. [CrossRef] [PubMed]

174. Ensign, L.M.; Cone, R.; Hanes, J. Oral drug delivery with polymeric nanoparticles: The gastrointestinal mucus barriers. Adv. Drug Deliv. Rev. 2012, 64, 557-570. [CrossRef] [PubMed]

175. Urtti, A. Challenges and obstacles of ocular pharmacokinetics and drug delivery. Adv. Drug Deliv. Rev. 2006, 58, 1131-1135. [CrossRef] [PubMed]

176. Gniewek, P.; Kolinski, A. Coarse-grained modeling of mucus barrier properties. Biophys. J. 2012, 102, $195-200$. [CrossRef] [PubMed]

177. Perez-Vilar, J.; Mabolo, R. Gel-forming mucins. Notions from in vitro studies. Histol. Histopathol. 2007, 22, 455-464. [PubMed]

178. Lai, S.K.; O'Hanlon, D.E.; Harrold, S.; Man, S.T.; Wang, Y.Y.; Cone, R.; Hanes, J. Rapid transport of large polymeric nanoparticles in fresh undiluted human mucus. Proc. Natl. Acad. Sci. USA 2007, 104, 1482-1487. [CrossRef] [PubMed]

179. Norris, D.A.; Sinko, P.J. Effect of size, surface charge, and hydrophobicity on the translocation of polystyrene microspheres through gastrointestinal mucin. J. Appl. Polym. Sci. 1997, 63, 1481-1492. [CrossRef]

180. Sakuma, S.; Sudo, R.; Suzuki, N.; Kikuchi, H.; Akashi, M.; Hayashi, M. Mucoadhesion of polystyrene nanoparticles having surface hydrophilic polymeric chains in the gastrointestinal tract. Int. J. Pharm. 1999, 177, 161-172. [CrossRef]

181. Dalsin, J.L.; Hu, B.H.; Lee, B.P.; Messersmith, P.B. Mussel adhesive protein mimetic polymers for the preparation of nonfouling surfaces. J. Am. Chem. Soc. 2003, 125, 4253-4258. [CrossRef] [PubMed]

182. Kojima, C.; Fukada, H.; Inui, T. Synthesis and binding properties of peptidomimetics based on a dendritic polymer. Polym. J. 2013, 45, 339-345. [CrossRef]

183. Tang, Z.Y.; Wang, Y.; Podsiadlo, P.; Kotov, N.A. Biomedical applications of layer-by-layer assembly: From biomimetics to tissue engineering. Adv. Mater. 2007, 19, 906. [CrossRef]

184. Sill, T.J.; von Recum, H.A. Electro spinning: Applications in drug delivery and tissue engineering. Biomaterials 2008, 29, 1989-2006. [CrossRef] [PubMed]

185. Geckil, H.; Xu, F.; Zhang, X.H.; Moon, S.; Demirci, U. Engineering hydrogels as extracellular matrix mimics. Nanomedicine UK 2010, 5, 469-484. [CrossRef] [PubMed]

186. Lee, M.; Cho, B.K.; Zin, W.C. Supramolecular structures from rod-coil block copolymers. Chem. Rev. 2001, 101, 3869-3892. [CrossRef] [PubMed]

187. Lee, J.H.; Choi, Y.J.; Lim, Y.B. Self-assembled filamentous nanostructures for drug/gene delivery applications. Expert Opin. Drug Deliv. 2010, 7, 341-351. [CrossRef] [PubMed]

188. Discher, D.E.; Eisenberg, A. Polymer vesicles. Science 2002, 297, 967-973. [CrossRef] [PubMed]

189. Geng, Y.; Dalhaimer, P.; Discher, D. Synthetic filamentous phages from self-assembling biocompatible diblock copolymers. Abstr. Pap. Am. Chem. Soc. 2005, 229, U970.

190. Kim, T.H.; Mount, C.W.; Dulken, B.W.; Ramos, J.; Fu, C.J.; Khant, H.A.; Chiu, W.; Gombotz, W.R.; Pun, S.H. Filamentous, mixed micelles of triblock copolymers enhance tumor localization of indocyanine green in a murine xenograft model. Mol. Pharm. 2012, 9, 135-143. [CrossRef] [PubMed]

191. Dalhaimer, P.; Engler, A.J.; Parthasarathy, R.; Discher, D.E. Targeted worm micelles. Biomacromolecules 2004, 5, 1714-1719. [CrossRef] [PubMed]

192. Dalhaimer, P.; Discher, D.E. Targeted worm micelles for drug delivery. Abstr. Pap. Am. Chem. Soc. 2004, 228, U495. 
193. Discher, D.E.; Dalhaimer, P.; Engler, A.J.; Parthasarthy, R. Targeted worm-like micelles. Abstr. Pap. Am. Chem. Soc. 2005, 230, U4026-U4027.

194. Geng, Y.; Dalhaimer, P.; Cai, S.S.; Tsai, R.; Tewari, M.; Minko, T.; Discher, D.E. Shape effects of filaments versus spherical particles in flow and drug delivery. Nat. Nanotechnol. 2007, 2, 249-255. [CrossRef] [PubMed]

195. Shuvaev, V.V.; Ilies, M.A.; Simone, E.; Zaitsev, S.; Kim, Y.; Cai, S.; Mahmud, A.; Dziubla, T.; Muro, S.; Discher, D.E.; et al. Endothelial targeting of antibody-decorated polymeric filomicelles. ACS Nano 2011, 5, 6991-6999. [CrossRef] [PubMed]

196. Pal, J.; Sanwaria, S.; Srivastava, R.; Nandan, B.; Horechyy, A.; Stamm, M.; Chen, H.L. Hairy polymer nanofibers via self-assembly of block copolymers. J. Mater. Chem. 2012, 22, 25102-25107. [CrossRef]

197. Mahalingam, A.; Jay, J.I.; Langheinrich, K.; Shukair, S.; McRaven, M.D.; Rohan, L.C.; Herold, B.C.; Hope, T.J.; Kiser, P.F. Inhibition of the transport of HIV in vitro using a $\mathrm{pH}$-responsive synthetic mucin-like polymer system. Biomaterials 2011, 32, 8343-8355. [CrossRef] [PubMed]

198. Xu, J.; Yang, D.G.; Li, W.J.; Gao, Y.; Chen, H.B.; Li, H.M. Phenylboronate-diol crosslinked polymer gels with reversible sol-gel transition. Polymer 2011, 52, 4268-4276. [CrossRef]

199. Guo, Q.Q.; Wu, Z.M.; Zhang, X.G.; Sun, L.; Li, C.X. Phenylboronate-diol crosslinked glycopolymeric nanocarriers for insulin delivery at physiological ph. Soft Matter 2014, 10, 911-920. [CrossRef] [PubMed]

200. Li, W.J.; Liu, M.N.; Chen, H.B.; Xu, J.; Gao, Y.; Li, H.M. Phenylboronate-diol crosslinked polymer/SWCNT hybrid gels with reversible sol-gel transition. Polym. Adv. Technol. 2014, 25, 233-239. [CrossRef]

201. Cook, M.T.; Smith, S.L.; Khutoryanskiy, V.V. Novel glycopolymer hydrogels as mucosa-mimetic materials to reduce animal testing. Chem. Commun. 2015, 51, 14447-14450. [CrossRef] [PubMed]

202. Rabuka, D.; Parthasarathy, R.; Lee, G.S.; Chen, X.; Groves, J.T.; Bertozzi, C.R. Hierarchical assembly of model cell surfaces: Synthesis of mucin mimetic polymers and their display on supported bilayers. J. Am. Chem. Soc. 2007, 129, 5462-5471. [CrossRef] [PubMed]

203. Rabuka, D.; Forstner, M.B.; Groves, J.T.; Bertozzi, C.R. Noncovalent cell surface engineering: Incorporation of bioactive synthetic glycopolymers into cellular membranes. J. Am. Chem. Soc. 2008, 130, 5947-5953. [CrossRef] [PubMed]

204. Godula, K.; Rabuka, D.; Nam, K.T.; Bertozzi, C.R. Synthesis and microcontact printing of dual end-functionalized mucin-like glycopolymers for microarray applications. Angew. Chem. Int. Ed. Engl. 2009, 48, 4973-4976. [CrossRef] [PubMed]

205. Godula, K.; Bertozzi, C.R. Density variant glycan microarray for evaluating cross-linking of mucin-like glycoconjugates by lectins. J. Am. Chem. Soc. 2012, 134, 15732-15742. [CrossRef] [PubMed]

206. Authimoolam, S.P.; Puleo, D.A.; Dziubla, T.D. Affinity based multilayered polymeric self-assemblies for oral wound applications. Adv. Healthc. Mater. 2013, 2, 983-992. [CrossRef] [PubMed]

207. Hamed, R.; Fiegel, J. Synthetic tracheal mucus with native rheological and surface tension properties. J. Biomed. Mater. Res. A 2014, 102, 1788-1798. [CrossRef] [PubMed]

208. Groo, A.C.; Mircheva, K.; Bejaud, J.; Ailhas, C.; Panaiotov, I.; Saulnier, P.; Ivanova, T.; Lagarce, F. Development of 2D and 3D mucus models and their interactions with mucus-penetrating paclitaxel-loaded lipid nanocapsules. Pharm. Res. 2014, 31, 1753-1765. [CrossRef] [PubMed]

209. Burruano, B.T.; Schnaare, R.L.; Malamud, D. Synthetic cervical mucus formulation. Contraception 2002, 66, 137-140. [CrossRef]

210. Burruano, B.T.; Schnaare, R.L.; Malamud, D. In vitro test to evaluate the interaction between synthetic cervical mucus and vaginal formulations. AAPS PharmSciTech 2004, 5, E17. [PubMed]

211. Wang, W.; Chance, D.L.; Mossine, V.V.; Mawhinney, T.P. Raft-based tri-component fluorescent glycopolymers: Synthesis, characterization and application in lectin-mediated bacterial binding study. Glycoconj. J. 2014, 31, 133-143. [CrossRef] [PubMed]

212. Pieters, R.J. Intervention with bacterial adhesion by multivalent carbohydrates. Med. Res. Rev. 2007, 27, 796-816. [CrossRef] [PubMed]

213. Imberty, A.; Chabre, Y.M.; Roy, R. Glycomimetics and glycodendrimers as high affinity microbial anti-adhesins. Chem. Eur. J. 2008, 14, 7490-7499. [CrossRef] [PubMed]

214. Shogren, R.; Gerken, T.A.; Jentoft, N. Role of glycosylation on the conformation and chain dimensions of o-linked glycoproteins: Light-scattering studies of ovine submaxillary mucin. Biochemistry 1989, 28, 5525-5536. [CrossRef] [PubMed] 
215. Levine, M.J.; Herzberg, M.C.; Levine, M.S.; Ellison, S.A.; Stinson, M.W.; Li, H.C.; Vandyke, T. Specificity of salivary-bacterial interactions-Role of terminal sialic-acid residues in interaction of salivary glycoproteins with streptococcus-sanguis and streptococcus-mutans. Infect. Immun. 1978, 19, 107-115. [PubMed]

216. Stinson, M.W.; Levine, M.J.; Cavese, J.M.; Prakobphol, A.; Murray, P.A.; Tabak, L.A.; Reddy, M.S. Adherence of streptococcus-sanguis to salivary mucin bound to glass. J. Dent. Res. 1982, 61, 1390-1393. [CrossRef] [PubMed]

217. Hall, D.J.; Khutoryanskaya, O.V.; Khutoryanskiy, V.V. Developing synthetic mucosa-mimetic hydrogels to replace animal experimentation in characterisation of mucoadhesive drug delivery systems. Soft Matter 2011, 7,9620-9623. [CrossRef]

218. Lee, C.T.; Huang, C.P.; Lee, Y.D. Biomimetic porous scaffolds made from poly(L-lactide)-g-chondroitin sulfate blend with poly(L-lactide) for cartilage tissue engineering. Biomacromolecules 2006, 7, 2200-2209. [CrossRef] [PubMed]

(C) 2016 by the authors; licensee MDPI, Basel, Switzerland. This article is an open access article distributed under the terms and conditions of the Creative Commons by Attribution (CC-BY) license (http:/ / creativecommons.org/licenses/by/4.0/). 